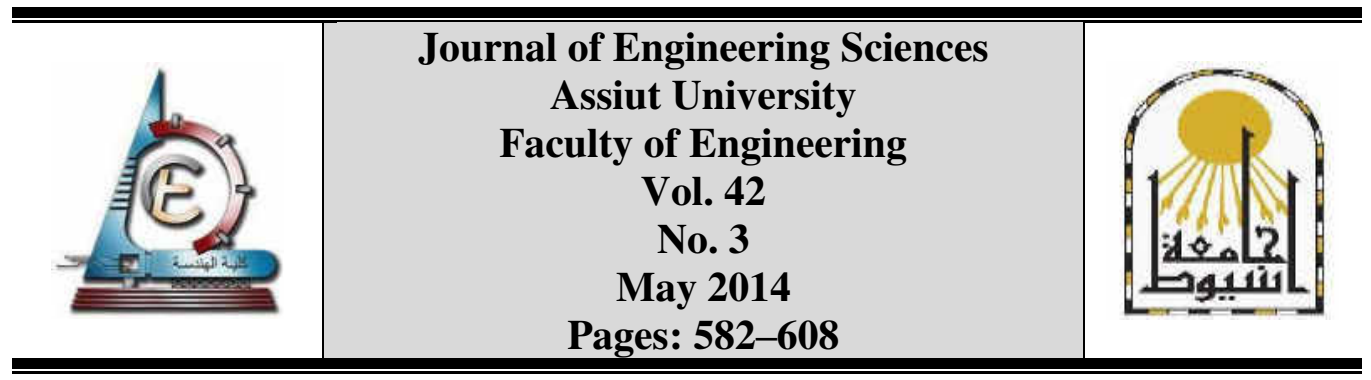

\title{
PROPERTIES OF HIGH STRENGTH CONCRETE CONTAINING ELECTRIC ARC FURNACE STEEL SLAG AGGREGATE
}

\author{
Mohamed Ahmed Khafaga ${ }^{1}$, Walid Safwat Fahmy ${ }^{2}$, \\ Mohamed Amen Sherif ${ }^{3}$ and Asmaa Mohamed Nageib Abdel Hamid ${ }^{4, *}$ \\ ${ }^{1}$ Housing and Building National Research Center, Egypt \\ ${ }^{2}$ Faculty of Petroleum and Mining Engineering, Suez University, Egypt \\ ${ }^{3}$ Depart. of Civil and Architectural Constructions, Faculty of Industrial Education, Suez Univ., Egypt \\ ${ }^{4}$ Faculty of Industrial Education, Sohag University, Egypt
}

Received 12 February 2014; revised 5 March 2014; accepted 27 March 2014

\begin{abstract}
Steel slag is produced as by-product during the oxidation of steel pellets in an electric arc furnace. This by-product can be broken down to smaller sizes to be used as aggregates in asphalt and concrete. In the current research, locally produced steel slag in Egypt was used as a replacement of the natural aggregate for producing high strength concrete. Four groups consisted of twenty-four normal, high and ultra-high strength concrete mixtures with replacement percentages $0 \%, 33.33 \%$, $66.67 \%$ and $100 \%$ by weight of the coarse aggregate with two cement contents $\left(450 \mathrm{~kg} / \mathrm{m}^{3}\right.$ and 600 $\left.\mathrm{kg} / \mathrm{m}^{3}\right)$ and three silica fume percentages $(0 \%, 10 \%$ and $20 \%)$ were investigated. In addition, other three groups consists of six concrete mixes of cement contents $350 \mathrm{~kg} / \mathrm{m}^{3}$ and $450 \mathrm{~kg} / \mathrm{m}^{3}$ were cast to study the possibility of using the fine electric arc furnace steel slag particles as a replacement of the used natural fine aggregate in the concrete mixtures. The effect of the studied key parameters which are the replacement ratio of the used electric arc furnace steel slag (EAFSS), the cement content and the silica fume percentage on the volume weight, compressive strength, flexural strength, indirect tensile strength, static of elasticity modulus and Permeability coefficient were studied. The results indicated that the highest concrete strength was obtained for the mixtures possessed a percentage of $66.67 \%$ steel slag aggregates as a replacement of the coarse aggregate. Moreover, the replacement of the natural fine aggregate by the fine steel slag as well as the EAFSS coarse aggregate produced a high strength pervious porous concrete.
\end{abstract}

Keywords: Electric Arc Furnace Steel Slag, High Strength Concrete, Coarse Aggregate, Fine Aggregate, Compressive Strength, Indirect Tensile Strength, Flexural Strength, Modulus of Elasticity and Permeability.

\section{Introduction}

Steel slag is an industrial by-product obtained during melting of steel scrap from the impurities and fluxing agents, which form the liquid slag floating over the electrical arc

\footnotetext{
* Corresponding author.

Email address:naden1953@yahoo.com
} 
furnaces (EAF). Steel slag is defined by the American Society for Testing and Materials (ASTM) as a non-metallic product, consisting essentially of calcium silicates and ferrites combined with fused oxides of iron, aluminum, manganese, calcium and magnesium that are developed simultaneously with steel in basic oxygen, electric arc furnaces, [1]. Steel slag was used in concrete to improve its mechanical, physical, and chemical properties. On the other hand, the use of steel slag has a positive effect on both compressive and tensile strengths; hence introducing it in concrete will eliminate one of the environmental problems created by the steel industry, [2, 3]. Experimental results obtained by Patel, [4], indicated that such steel slag aggregate concrete achieved higher values of mechanical properties, compared to natural aggregate concrete. Similar studies have been conducted on the utilization of steel slag as aggregate is advantages when compared with normal aggregate mixes $[5,6,7]$. On the other hand, experimental researches indicated that the results steel slag aggregate concrete achieved the strength performance of EAFSS concretes is similar to that of a more traditional concrete, with a higher compressive strength and a slightly less flexural strength, $[8,9,10]$. This research aims to investigate the effect of using the locally produced electric arc furnace steel slag (EAFSS) in Egypt as a replacement of the natural coarse or fine aggregate on the properties of normal, high and ultra-high strength concrete. Properties of fresh and hardened concrete were evaluated for thirty concrete mixes. Twenty-four concrete mixtures were prepared with different percentage of replacement $(0 \%, 33.33 \%, 66.67 \%$ and $100 \%)$ by weight of slag coarse aggregate. Other six concrete mixes were prepared to study the effect of using EAFSS as fine aggregate on the properties of the produced concrete. The experimental work was carried out at the materials laboratory of housing and building national research center in Egypt.

\section{Experimental program}

\subsection{Materials}

- The cement used in this investigation was CEM I $42.5 \mathrm{~N}$. Testing of cement was carried out as per the Egyptian Standard Specifications ESS 2421/2005[11].

- The used silica fume was locally produced in Egypt. The chemical composition and physical as obtained from the manufactures, sheet is shown in Tables (1) and (2), respectively. Table (1) shows that the content of $\mathrm{SiO}_{2}$ in the used silica fume is $96.89 \%$ while Table (2) shows that the particles size of the used silica fume is in the micro-scale.

Table 1.

Chemical composition of the used silica fume

\begin{tabular}{|l|c|c|c|c|c|c|c|c|c|}
\hline Oxide & $\mathrm{SiO}_{2}$ & $\mathrm{Fe}_{2} \mathrm{O}_{3}$ & $\mathrm{Al}_{2} \mathrm{O}_{3}$ & $\mathrm{CaO}$ & $\mathrm{MgO}$ & $\mathrm{K}_{2} \mathrm{O}$ & $\mathrm{Na}_{2} \mathrm{O}$ & $\mathrm{SO}_{3}$ & $\mathrm{H}_{2} \mathrm{O}$ \\
\hline Content \% & 96.89 & 0.56 & 1.03 & 0.21 & 0.15 & 0.62 & 0.17 & 0.16 & 0.21 \\
\hline
\end{tabular}

* The data were obtained from the manufacturer data sheet.

Table 2.

Physical properties of the used silica fume

\begin{tabular}{|l|c|}
\hline \multicolumn{1}{|c|}{ Property } & Results* \\
\hline Specific gravity & 2.15 \\
\hline Bulk density $\left(\mathrm{t} / \mathrm{m}^{3}\right)$ & 0.345 \\
\hline
\end{tabular}


JES, Assiut University, Faculty of Engineering, Vol. 42, No. 3, May2014, pp. 582-608

\begin{tabular}{|l|c|}
\hline \multicolumn{1}{|c|}{ Property } & Results* \\
\hline Specific surface area $\left(\mathrm{m}^{2} / \mathrm{kg}\right)$ & $17.8 \times 10^{3}$ \\
\hline Particle size $(\mu \mathrm{m})$ & 7.00 \\
\hline Color & Light gray \\
\hline
\end{tabular}

* The data were obtained from the manufacturer data sheet.

- A high performance super plasticizer admixture of aqueous solution of modified polycarboxylate basis (Viscocrete-5930) was used to increase workability and viscosity (strong self-compacting behavior) of the concrete mixes. Viscocrete-5930 complies with ASTM-C-494 types G and F, and BS EN 934 part 2: 2001. The dosage of the admixture was adjusted to minimize the water/cement ratio.

- A clean tap drinking water was used in all mixtures.

- A natural sand composed of siliceous materials was used as fine aggregate in this study. Testing of sand was carried out according to the ESS 1109/2002, [12]. Its specific weight was 2.63 and volume weight was $1.78 \mathrm{t} / \mathrm{m}^{3}$. Table (3) show grading of used fine aggregate.

- A natural crushed dolomite stone from Ataka in Suez City in Egypt was used in the experimental work. It had a nominal maximum size of $14 \mathrm{~mm}$. Table (4) show grading of the used coarse aggregate. Testing of natural coarse aggregate was carried out according to the Egyptian Standard Specification (1109/2002),[12]. The mechanical and physical properties complied with both ESS 1109/2002, [12], and the Egyptian Code ECCS203-2007, [13]. Table (5) shows the physical and mechanical properties of the used natural crushed dolomite stone.

Table 3.

Grading of natural fine aggregate

\begin{tabular}{|c|c|c|c|c|c|c|c|}
\hline Sieve Size (mm) & 10 & 5 & 2.36 & 1.18 & 0.6 & 0.3 & 0.15 \\
\hline Passing \% & 100 & 97.2 & 89.5 & 72.1 & 38.9 & 10.3 & 3.2 \\
\hline
\end{tabular}

Table 4.

Grading of natural crushed dolomite aggregate

\begin{tabular}{|c|c|c|c|c|c|c|c|}
\hline Sieve Size (mm) & 50 & 37.5 & 20 & 14 & 10 & 5 & 2.36 \\
\hline Passing \% & 100 & 100 & 100 & 100 & 78.30 & 6.26 & 0 \\
\hline
\end{tabular}

\section{Table 5.}

Physical and mechanical properties of natural coarse aggregate

\begin{tabular}{|l|c|c|}
\hline \multicolumn{1}{|c|}{ Property } & Results & Limits \\
\hline Specific gravity & 2.65 & - \\
\hline Bulk density $\left(\mathrm{t} / \mathrm{m}^{3}\right)$ & 1.65 & - \\
\hline Water absorption \% & 2.05 & Not more than $2.5 \% * *$ \\
\hline Impact Coefficient \% & 10.00 & Not more than $30 \%$ ** \\
\hline Los Angles Abrasion Coefficient \% & 18.50 & Not more than $30 \% *$ \\
\hline Crushing Coefficient \% & 22.00 & Not more than $30 \% *$ \\
\hline Clay and fine dust content \% & 0.92 & Not more than $4 \% *$ \\
\hline
\end{tabular}

* Limits of ESS 1109/2002 [14]

** Limits of ECCS203-2007 [15]

- The used local electric arc furnace steel slag (EAFSS) was obtained from Ezz steel industry factory in Suez. The EAFSS is a by-product during melting of steel scrap from the impurities and fluxing agents, which form the liquid slag floating over the 
liquid crude iron or steel in electrical arc furnaces. The chemical properties of the used EAFSS as obtained from the manufacture are shown in Table (6). The physical and mechanical properties of the steel slag coarse aggregate were determined and shown in Table (7). The specific gravity, bulk density, water absorption, coefficient of impact abrasion coefficient and coefficient of crushing were obtained. From Tables ( 5 and 7 ), it can be noticed that the specific gravity of the EAFSS aggregate equals 3.46 while the natural aggregate recorded a specific gravity value equals 2.65. This means that the local used EAFSS aggregate are heavier than the natural aggregate by about $31 \%$. On the other hand, the 24 -h water absorption in the EAFSS aggregate was much lower than that of the natural aggregate. The water absorption increased from 1.0\% for the EAFSS aggregate to $2.05 \%$ for natural aggregate. Also, as illustrated in these tables, the coefficients of impact, abrasion and crushing of EAFSS aggregate showed lower values if compared to the natural aggregate. These results indicated better physical and mechanical properties of the EAFSS aggregate if compared to the natural aggregate. The EAFSS was crushed to the same size of the natural coarse aggregate (maximum nominal size $=14 \mathrm{~mm}$ ) using a crusher in the laboratory, see Figure (1). During crushing, fine particles were produced. These fine particles were separated to be used as fine aggregate. Tables (8) and (9) show grading of the used coarse and fine aggregate.

\section{Table 6.}

Chemical properties of steel slag coarse aggregates

\begin{tabular}{|l|c|c|c|c|c|c|c|c|}
\hline Constituent & $\mathrm{Si}_{\mathrm{O} 2}$ & $\mathrm{Fe}_{\mathrm{x}} \mathrm{O}_{\mathrm{y}}$ & $\mathrm{Al}_{2} \mathrm{O}_{3}$ & $\mathrm{CaO}$ & $\mathrm{MgO}$ & $\mathrm{MnO}$ & $\mathrm{Cr}_{2} \mathrm{O}_{3}$ & $\mathrm{TiO}_{2}$ \\
\hline Composition\% & 13.10 & 36.80 & 5.510 & 33.0 & 5.030 & 4.180 & 0.775 & 0.598 \\
\hline
\end{tabular}

* The data were obtained by the manufacturer data sheet.

\section{Table 7.}

Physical and mechanical properties of steel slag coarse aggregates

\begin{tabular}{|l|c|}
\hline \multicolumn{1}{|c|}{ Property } & Results \\
\hline Specific gravity & 3.48 \\
\hline Bulk density, $\mathrm{t} / \mathrm{m}^{3}$ & 1.97 \\
\hline Water Absorption \% & 1.00 \\
\hline Impact coefficient \% & 6.60 \\
\hline Los Angles Abrasion coefficient \% & 13.50 \\
\hline Crushing coefficient \% & 11.40 \\
\hline
\end{tabular}

\section{Table 8.}

Grading of EAFSS as coarse aggregate

\begin{tabular}{|c|c|c|c|c|c|c|c|}
\hline Sieve Size (mm) & 50 & 37.5 & 20 & 14 & 10 & 5 & 2.36 \\
\hline Passing \% & 100 & 100 & 100 & 97.60 & 62.70 & 5.08 & 0.16 \\
\hline
\end{tabular}


Table 9.

Grading of EAFSS as fine aggregate

\begin{tabular}{|c|c|c|c|c|c|c|c|}
\hline Sieve Size (mm) & 10 & 5 & 2.36 & 1.18 & 0.6 & 0.3 & 0.15 \\
\hline Passing \% & 100 & 97 & 72 & 37 & 21 & 11 & 2.8 \\
\hline
\end{tabular}

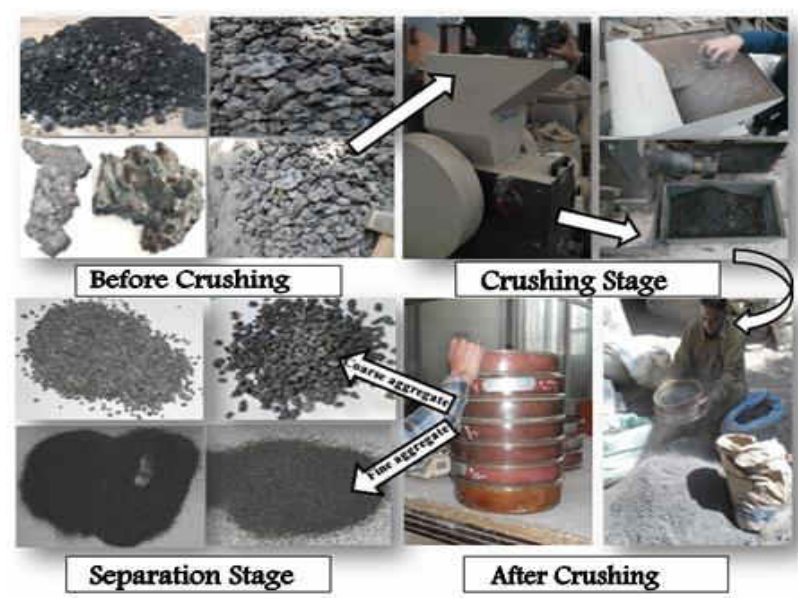

Fig. 1. Production of EAFSS Coarse Aggregate at the Laboratory

\subsection{Concrete mixes}

Table (10) illustrates the mix proporions of the thirty concrete mixes which were investigated in the current study. These concrete mixes reflect the key parameters aimed to be studied in the current research. The concrete mixes were divided into seven groups, M1, M2, M3, M4, M5, M6 and M7. In the first four groups, the percentages of replacement of the natural coarse aggregate by the steel slag coarse aggregate were $0 \%, 33.33 \%, 66.67 \%$ and $100 \%$, respectively. In the last two groups, M5, M6 and M7, both coarse and fine steel slag aggregate were used with percentage $100 \%$. The ratio of fine to coarse aggregate for the all studied concrete mixes was $1: 2$. Three cement contents of $350 \mathrm{~kg} / \mathrm{m}^{3}, 450 \mathrm{~kg} / \mathrm{m}^{3}$ and $600 \mathrm{~kg} / \mathrm{m}^{3}$ were used in the studied mixes and three ratios of silica fume $(0 \%, 10 \%$ and $20 \%$ ) were also used as addition to cement. Water to binder materials ratio (w/b) was used as 0.35 for mixes of cement content $350 \mathrm{~kg} / \mathrm{m}^{3}, 0.30$ for mixes of cement content 450 $\mathrm{kg} / \mathrm{m}^{3}$ and 0.22 for mixes cement content $600 \mathrm{~kg} / \mathrm{m}^{3}$. These ratios were chosen after trial mixes to achieve the lowest water to binder ratios can allow to produce homogenous mixes and sufficient for hydration of binder materials for producing high strength concretes. Superplasticizer dosage ranged from $2.5 \%$ to $3.0 \%$ of cement content.

\subsection{Concrete tests}

All of the concrete mixes were mixed mechanically in the laboratory of building materials at Housing and Building National Research Center in Egypt. The slump test was conducted on fresh concrete to determine the effects of the studied parameter on the workability of the concrete. For each concrete mix, nine $150 \times 150 \times 150 \mathrm{~mm}$ cubes were cast for the determination of compressive strength at 7, 28 and 91 days, three $150 \times 300$ $\mathrm{mm}$ cylinders were cast for the determination of indirect tensile strength at 91 days, three beams of dimensions $100 \times 100 \times 500 \mathrm{~mm}$ were cast for the determination of flexural strength at 91 days, three $150 \times 300 \mathrm{~mm}$ cylinders were cast for the determination of static 
modulus of elasticity at 91 days, and three $150 \times 150 \mathrm{~mm}$ cylinders were cast for the determination of coefficient of permeability.

Table 10.

Proportions of concrete mixes

\begin{tabular}{|c|c|c|c|c|c|c|c|c|c|}
\hline $\begin{array}{c}\text { Grou } \\
\mathrm{p}\end{array}$ & $\begin{array}{c}\text { Mix } \\
\text { No }\end{array}$ & $\begin{array}{r}\text { Cement } \\
\text { Content } \\
\left(\mathrm{kg} / \mathrm{m}^{3}\right)\end{array}$ & $\begin{array}{c}\wedge \mathrm{SF} \\
\%\end{array}$ & $\begin{array}{c}\text { SSCA } \\
\%\end{array}$ & $\begin{array}{c}{ }^{* * *} \mathrm{NCA} \\
\%\end{array}$ & $\begin{array}{c}\text { w.** }^{* * *} \\
\text { SSFA } \\
\%\end{array}$ & $\begin{array}{c}{ }^{* * *} \\
\wedge \mathrm{NFA}\end{array}$ & $\begin{array}{c}{ }^{* * * * *} \\
\mathrm{SP} / \mathrm{C} \\
\%\end{array}$ & $\begin{array}{c}{ }^{* * * * * *} \\
\mathrm{w} / \mathrm{b} \\
\%\end{array}$ \\
\hline \multirow{6}{*}{ M1 } & M1.1 & 450 & 0 & \multirow{6}{*}{0} & \multirow{6}{*}{100} & \multirow{6}{*}{0} & \multirow{6}{*}{100} & 3.0 & 0.30 \\
\hline & M1.2 & 450 & 10 & & & & & 3.0 & 0.30 \\
\hline & M1.3 & 450 & 20 & & & & & 2.5 & 0.30 \\
\hline & M1.4 & 600 & 0 & & & & & 3.0 & 0.22 \\
\hline & M1.5 & 600 & 10 & & & & & 3.0 & 0.22 \\
\hline & M1.6 & 600 & 20 & & & & & 2.5 & 0.22 \\
\hline \multirow{6}{*}{ M2 } & M2.1 & 450 & 0 & \multirow{6}{*}{33.33} & \multirow{6}{*}{66.67} & \multirow{6}{*}{0} & \multirow{6}{*}{100} & 3.0 & 0.30 \\
\hline & M2.2 & 450 & 10 & & & & & 3.0 & 0.30 \\
\hline & M2.3 & 450 & 20 & & & & & 2.5 & 0.30 \\
\hline & M2.4 & 600 & 0 & & & & & 3.0 & 0.22 \\
\hline & M2.5 & 600 & 10 & & & & & 3.0 & 0.22 \\
\hline & M2.6 & 600 & 20 & & & & & 2.5 & 0.22 \\
\hline \multirow{6}{*}{ M3 } & M3.1 & 450 & 0 & \multirow{6}{*}{66.67} & \multirow{6}{*}{33.33} & \multirow{6}{*}{0} & \multirow{6}{*}{100} & 3.0 & 0.30 \\
\hline & M3.2 & 450 & 10 & & & & & 3.0 & 0.30 \\
\hline & M3.3 & 450 & 20 & & & & & 2.5 & 0.30 \\
\hline & M3.4 & 600 & 0 & & & & & 3.0 & 0.22 \\
\hline & M3.5 & 600 & 10 & & & & & 3.0 & 0.22 \\
\hline & M3.6 & 600 & 20 & & & & & 2.5 & 0.22 \\
\hline \multirow{6}{*}{ M4 } & M4.1 & 450 & 0 & \multirow{6}{*}{100} & \multirow{6}{*}{0} & \multirow{6}{*}{0} & \multirow{6}{*}{100} & 3.0 & 0.30 \\
\hline & M4.2 & 450 & 10 & & & & & 3.0 & 0.30 \\
\hline & M4.3 & 450 & 20 & & & & & 2.5 & 0.30 \\
\hline & M4.4 & 600 & 0 & & & & & 3.0 & 0.22 \\
\hline & M4.5 & 600 & 10 & & & & & 3.0 & 0.22 \\
\hline & M4.6 & 600 & 20 & & & & & 2.5 & 0.22 \\
\hline \multirow{2}{*}{ M5 } & M5.1 & 350 & 0 & \multirow[b]{2}{*}{0} & \multirow{2}{*}{100} & \multirow{2}{*}{0} & \multirow{2}{*}{100} & 3.0 & 0.35 \\
\hline & M5.2 & 350 & 20 & & & & & 2.5 & 0.35 \\
\hline & M6.1 & 350 & 0 & & & & & 3.0 & 0.35 \\
\hline M6 & M6.2 & 350 & 20 & 100 & 0 & 100 & 0 & 2.5 & 0.35 \\
\hline & M7.1 & 450 & 0 & & & & & 3.0 & 0.30 \\
\hline M7 & M7.2 & 450 & 20 & 100 & 0 & 100 & 0 & 2.5 & 0.30 \\
\hline & SF & & lica $f$ & & & & & & \\
\hline$*$ & SSCA & & teel s & g coarse & ggregat & & & & \\
\hline$* *$ & $\mathrm{NCA}$ & & atura & oarse a & regate & & & & \\
\hline$* * *$ & SSFA & & eel sl & fine ag & egate & & & & \\
\hline$* * * \wedge$ & NFA & & atura & ine agg & gate & & & & \\
\hline$* * * *$ & $\mathrm{SP} / \mathrm{C}$ & & erpla & zer to $\mathrm{c}$ & nent per & ntage & & & \\
\hline$* * * * *$ & $\mathrm{w} / \mathrm{b}$ & W & er to & nder ma & rials rat & & & & \\
\hline
\end{tabular}




\section{Results and discussion}

\subsection{Fresh concrete properties}

\subsubsection{Effect of replacement percentage of EAFSS coarse aggregate (groups $M 1, M 2, M 3$ and M4).}

Figures (2-a) and (2-b), show the relationships between the slump values of concrete and the replacement percentage of EAFSS coarse aggregate for mixes of cement contents equal $450 \mathrm{~kg} / \mathrm{m}^{3}$ and $600 \mathrm{~kg} / \mathrm{m}^{3}$, respectively. In general, the use of slag without silica fume reduced the workability of concrete; the reason is due to that the surface texture, shape, porosity and the heavy specific weight of the EAFSS aggregate. The mixes without silica fume lacked mobility and hence resulted in low slump values. On the other hand, it can be noticed that improved values of slump were obtained when adding silica fume. Increasing the replacement ratio increased the slump value in mixes contained silica fume. These observations were noticed for both mixes of cement contents $450 \mathrm{~kg} / \mathrm{m}^{3}$ and 600 $\mathrm{kg} / \mathrm{m}^{3}$. It can be attributed to the fact that the use of silica fume increased the volume of the cement paste and reduced the aggregate content in the mixture. This led to increase the workability of the studied concrete mixes despite the lack in the used super plasticizer percentage in the mixes of $20 \%$ silica fume.

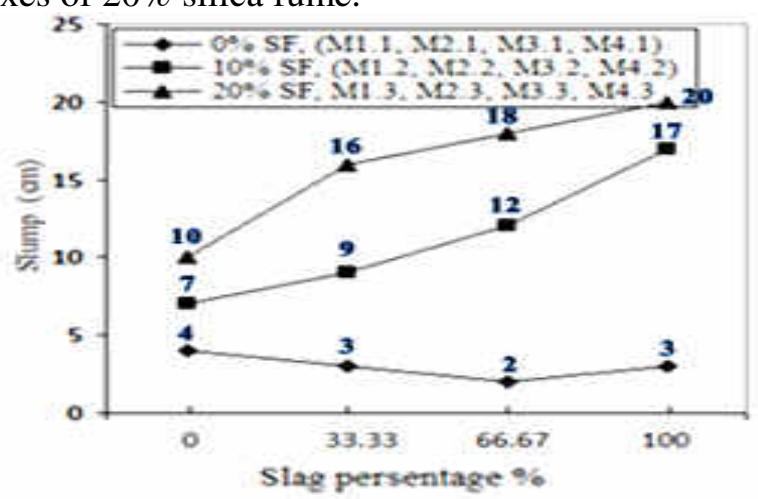

a) Slump of Concrete Mixes of Cement Content $450 \mathrm{~kg} / \mathrm{m}^{3}$

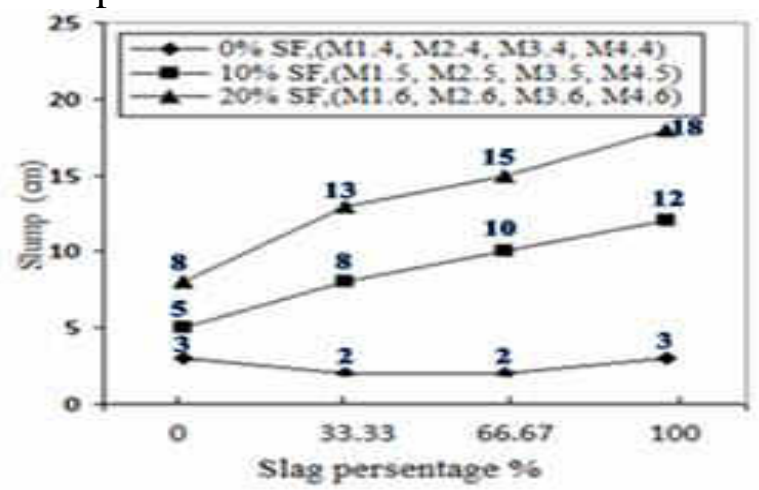

b) Slump of Concrete Mixes of Cement Content $600 \mathrm{~kg} / \mathrm{m}^{3}$

Fig. 2. (a, b) Effect of Replacement Percentage of EAFSS Coarse Aggregate on the Slump of the Concrete Mixes.

3.1.2. Effect of using EAFSS as coarse and fine aggregate (groups $m 5, m 6, m 7$ )

Figures (3-a) and (3-b), show the effect of using of EAFSS coarse and fine aggregate 
for mixes of cement contents equal $350 \mathrm{~kg} / \mathrm{m}^{3}$ and $450 \mathrm{~kg} / \mathrm{m}^{3}$, respectively. In general, the use of EAFSS as coarse and fine aggregate reduced the workability of the concrete mix and hence resulted in low slump values. The reduction in the workability is attributed to the fact that the sand has been replaced by the fine steel slag. Moreover, the voids ratio in the concrete mixes which possessed fine slag was found to be much higher than that of concrete possessed natural sand due to the increased angularity of the fine slag. The slump values in mixes contained silica fume were enhanced for mixes with and without steel slag aggregates. This observation was noticed for both mixes of cement content equal 350 $\mathrm{kg} / \mathrm{m}^{3}$ and $450 \mathrm{~kg} / \mathrm{m}^{3}$.

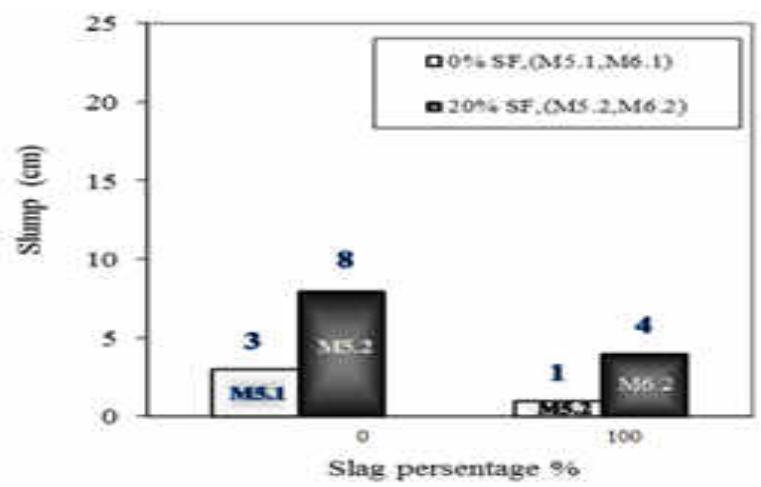

a) Slump of Concrete Mixes of Cement Content $350 \mathrm{~kg} / \mathrm{m}^{3}$

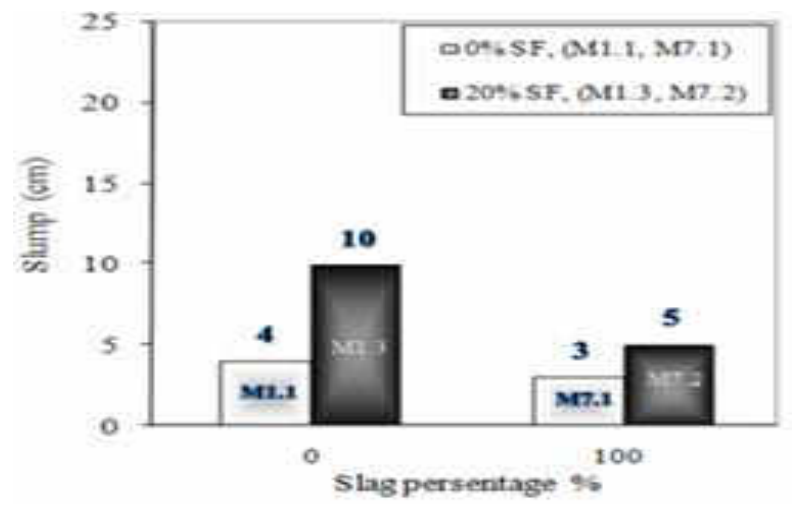

b) Slump of Concrete Mixes of Cement Content $450 \mathrm{~kg} / \mathrm{m}^{3}$

Fig. 3. (a., b.) Effect of Using of EAFSS Coarse and Fine Aggregate on the Slump of the Concrete Mixes.

\subsection{Hardened concrete properties}

\subsubsection{Unit weight}

The unit weight of the hardened concrete was determined for the concrete cubes just before carrying out the compression test. Table (11) illustrates the values of the unit weight of the mixes M1, M2, M3 and M4. Each value of the listed unit weight values in Table (11) is the average of nine values. It can be noticed that the unit weight of the EAFSS coarse aggregate concrete varied from $2.51 \mathrm{~g} / \mathrm{cm}^{3}$ to $2.82 \mathrm{~g} / \mathrm{cm}^{3}$. In general, it increased with the increase of the slag replacement percentage. On the other hand, the unit weight of the natural 
aggregate concrete ranged from $2.42 \mathrm{~g} / \mathrm{m}^{3}$ to $2.47 \mathrm{~g} / \mathrm{m}^{3}$. The higher unit weight of the steel slag aggregate concrete is attributed to the higher specific gravity of the steel slag aggregates.

\subsubsection{Compressive strength}

The development of compressive strength with age for the different studied mixes is presented in current section. The compressive strength of the studied mixes at ages 7, 28 and 91 are listed in Tables (11) and (12).

\subsubsection{Effect of replacement percentage of EAFSS coarse aggregate}

Figure (4-a) shows a comparison between the results of mixes M1.1, M2.1, M3.1 and M4.1 which possessed cement content equals $450 \mathrm{~kg} / \mathrm{m}^{3}$ without silica fume and replacement percentages of EAFSS equal $0 \%, 33.33 \%, 66.67 \%$ and $100 \%$, respectively. It can be observed that the concrete mix M2.1 which possessed replacement ratio of $33.33 \%$ recorded the highest compressive strength at all ages (7, 28 and 91 days). However, the compressive strength after 91 days for these mixes ranged from 64.0 MPa for mix M4.1 (100\% EAFSS) to $79.9 \mathrm{MPa}$ for mix M2.1 (33.33\% EAFSS). On the other hand, mix M1.1 (0\% EAFSS) recorded a compressive strength equals $75.2 \mathrm{MPa}$ after 91 days; i.e. using of $33.33 \%$ EAFSS as a replacement of the natural coarse aggregates led to an increase in the compressive strength equals $6.7 \%$. Similarly, Figures (4-b) and (4-c) show the effect of EAFSS content on the compressive strength of mixtures of cement content equals $450 \mathrm{~kg} / \mathrm{m}^{3}$ and possessed silica fume with ratios $10 \%$ and $20 \%$ as addition to cement, respectively. As illustrated in these figures, the compressive strength of mixes possessed $33.33 \%$ and $66.67 \%$ of EAFSS showed almost the same values recorded for the control mixes (0\% EAFSS) at ages 7 and 28 days. After that, the mixes of 66.67\% EAFSS (mixes M3.2 and M3.3) recorded a significant increase in the compressive strength after 91 days if compared to the control mixes (M1.2 and M1.3). This means that, when using silica fume as addition to cement with ratios $10 \%$ and $20 \%$ in the concrete mixes of cement content equals $450 \mathrm{~kg} / \mathrm{m}^{3}$, the replacement of $66.67 \%$ (by weight) of the natural coarse aggregate by EAFSS enhanced the compressive strength of the concrete mixes. It can be attributed to the enhancement in the cohesion between the aggregate particles and the surrounded cement mortar as well as the higher hardness of the used EAFSS aggregate. Also, Figure (5-a) shows a comparison between the results of mixes M1.4, M2.4, M3.4 and M4.4 which possessed cement content equals 600 $\mathrm{kg} / \mathrm{m}^{3}$ without silica fume and replacement percentages of EAFSS equal 0\%, 33.33\%, $66.67 \%$ and $100 \%$, respectively. It can be observed that the concrete mix M3.4 which possessed replacement ratio of $66.67 \%$ recorded the highest compressive strength at all ages (7, 28 and 91 days). However, the compressive strength after 91 days for these mixes ranged from 88.9 MPa for mix M1.4 (0\% EAFSS) to 106.7 MPa for mix M3.4 (66.67\% EAFSS). This means that, the using of $66.67 \%$ EAFSS as a replacement of the natural coarse aggregates led to an increase in the compressive strength equals $20.22 \%$. Also, this means that, the ultra-high strength concrete can be produced by using $66.67 \%$ EAFSS. Similarly, Figures (5-b) and (5-c) show the effect of EAFSS content on the compressive strength of mixtures of cement content equals $600 \mathrm{~kg} / \mathrm{m}^{3}$ and possessed silica fume with ratios $10 \%$ and $20 \%$ as addition to cement, respectively. As illustrated in these figures, mixes of $66.67 \%$ EAFSS (mixes M3.5 and M3.6) recorded the highest compressive strength at all ages (7, 28 and 91 days). The compressive strength for mixes M3.5 and M3.6 were $115.8 \mathrm{MPa}$ and 125.7 MPa, respectively, see Table (11). The increase in the compressive strength for mixes of $66.67 \%$ EAFSS as coarse aggregate reached $28.5 \%$ after 91 days in mix M3.6 if compared to the concrete mix (M1.6). In general, All mixes of $66.67 \%$ EAFSS and cement content 
equals $600 \mathrm{~kg} / \mathrm{m}^{3}$ (M3.4, M3.5 and M3.6) recorded compressive strength after 91 days higher than $100 \mathrm{MPa}$, i.e. these mixes could be considered as ultra-high strength concrete.

\section{Table 11.}

Volume weights and compressive strengths of the test concrete mixtures of groups M1, M2, M3 and M4 at ages 7, 28 and 91 days.

\begin{tabular}{|c|c|c|c|c|c|c|c|c|}
\hline \multirow[t]{2}{*}{ Group } & \multirow{2}{*}{$\begin{array}{c}\text { Mix } \\
\text { Ident }\end{array}$} & \multirow{2}{*}{$\begin{array}{c}\text { Cement } \\
\text { Content } \\
\left(\mathrm{kg} / \mathrm{m}^{3}\right)\end{array}$} & \multirow[t]{2}{*}{ SF\% } & \multirow[t]{2}{*}{ SSCA $\%$} & \multirow{2}{*}{$\begin{array}{l}\text { Volume } \\
\text { weight } \\
\left(\mathrm{g} / \mathrm{cm}^{3}\right)\end{array}$} & \multicolumn{3}{|c|}{$\begin{array}{c}\text { Compressive Strength } \\
\left(\mathrm{N} / \mathbf{m m}^{2}\right)\end{array}$} \\
\hline & & & & & & 7 Days & 28 Days & 91 Days \\
\hline \multirow{6}{*}{ M1 } & M1.1 & 450 & 0 & \multirow{6}{*}{0} & 2.42 & 58.3 & 60.8 & 75.2 \\
\hline & M1.2 & 450 & 10 & & 2.45 & 58.5 & 77.9 & 86.4 \\
\hline & M1.3 & 450 & 20 & & 2.46 & 63.6 & 80.8 & 88.4 \\
\hline & M1.4 & 600 & 0 & & 2.46 & 64.4 & 69.1 & 88.9 \\
\hline & M1.5 & 600 & 10 & & 2.45 & 67.0 & 84.5 & 94.2 \\
\hline & M1.6 & 600 & 20 & & 2.47 & 65.9 & 86.7 & 97.8 \\
\hline \multirow{6}{*}{ M2 } & M2.1 & 450 & 0 & \multirow{6}{*}{33.33} & 2.55 & 58.7 & 66.1 & 79.9 \\
\hline & M2.2 & 450 & 10 & & 2.52 & 59.4 & 76.5 & 88.6 \\
\hline & M2.3 & 450 & 20 & & 2.52 & 64.0 & 82.7 & 93.8 \\
\hline & M2.4 & 600 & 0 & & 2.53 & 65.7 & 74.8 & 94.3 \\
\hline & M2.5 & 600 & 10 & & 2.55 & 67.0 & 86.1 & 98.6 \\
\hline & M2.6 & 600 & 20 & & 2.51 & 74.8 & 89.9 & 102.9 \\
\hline \multirow{6}{*}{ M3 } & M3.1 & 450 & 0 & \multirow{6}{*}{66.67} & 2.65 & 53.2 & 60.2 & 72.4 \\
\hline & M3.2 & 450 & 10 & & 2.66 & 59.3 & 76.2 & 92.7 \\
\hline & M3.3 & 450 & 20 & & 2.58 & 64.9 & 80.6 & 98.4 \\
\hline & M3.4 & 600 & 0 & & 2.67 & 75.8 & 89.9 & 106.7 \\
\hline & M3.5 & 600 & 10 & & 2.65 & 77.6 & 102.3 & 115.8 \\
\hline & M3.6 & 600 & 20 & & 2.65 & 79.2 & 106.8 & 125.7 \\
\hline \multirow{6}{*}{ M4 } & M4.1 & 450 & 0 & \multirow{6}{*}{100.00} & 2.72 & 50.7 & 55.2 & 64.0 \\
\hline & M4.2 & 450 & 10 & & 2.77 & 57.3 & 75.2 & 87.3 \\
\hline & M4.3 & 450 & 20 & & 2.80 & 61.1 & 76.6 & 89.3 \\
\hline & M4.4 & 600 & 0 & & 2.76 & 57.4 & 68.5 & 90.4 \\
\hline & M4.5 & 600 & 10 & & 2.78 & 62.4 & 83.2 & 98.2 \\
\hline & M4.6 & 600 & 20 & & 2.82 & 72.8 & 86.2 & 110.3 \\
\hline
\end{tabular}

* Volume weight is the average of the test nine cubes (at ages 7,28 and 91 days).

** Compressive strengths are the average of the results of testing of three cubes at the same age.

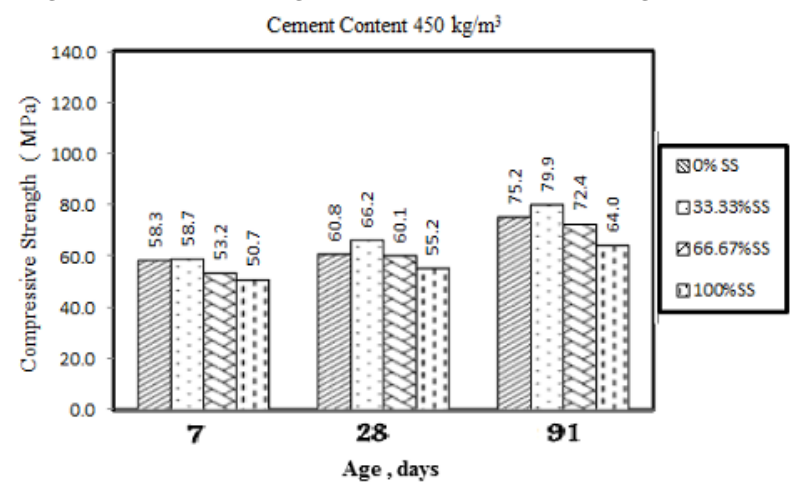

a) Mixes of $0 \%$ Silica Fume 


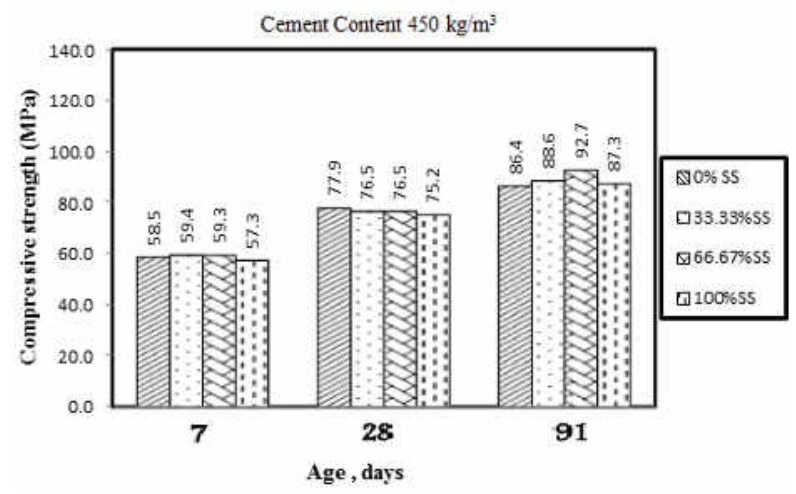

b) Mixes of $10 \%$ Silica Fume

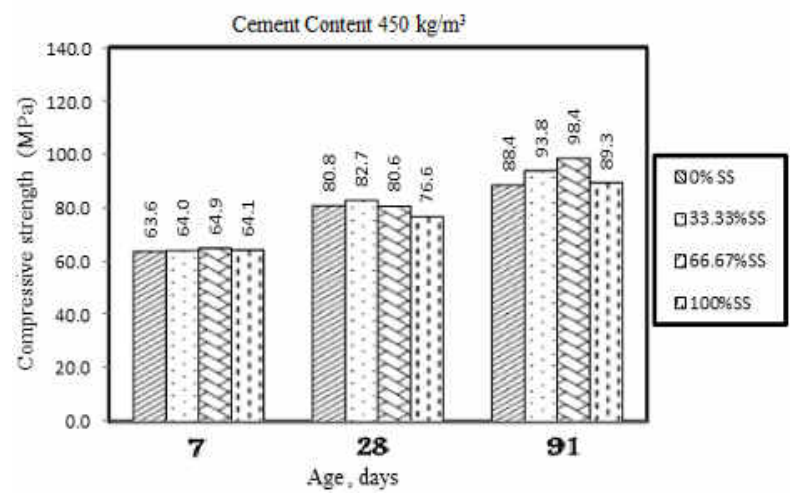

c. Mixes of $20 \%$ Silica Fume

Fig. 4. Effect of EAFSS Content in Mixes of Cement Content $450 \mathrm{~kg} / \mathrm{m}^{3}$ on the Compressive Strength

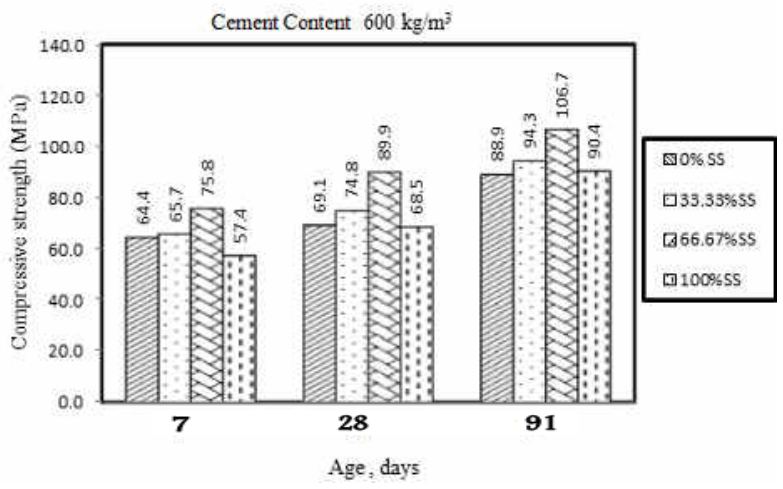

a) Mixes of $0 \%$ Silica Fume 


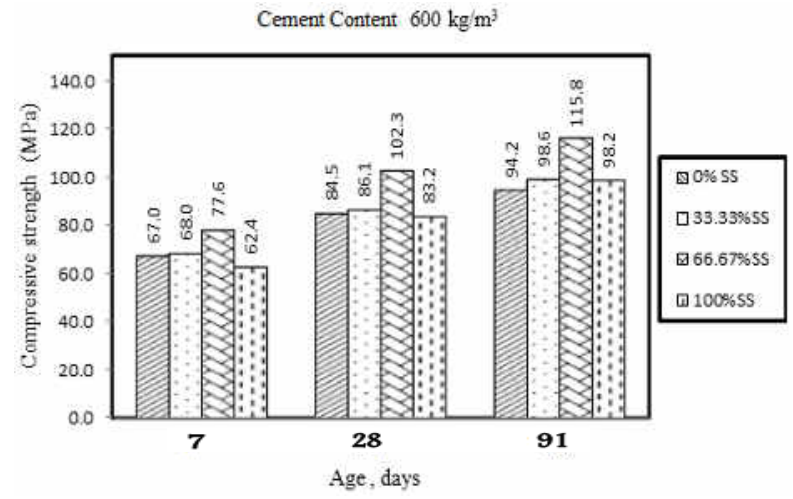

b) Mixes of $10 \%$ Silica Fume

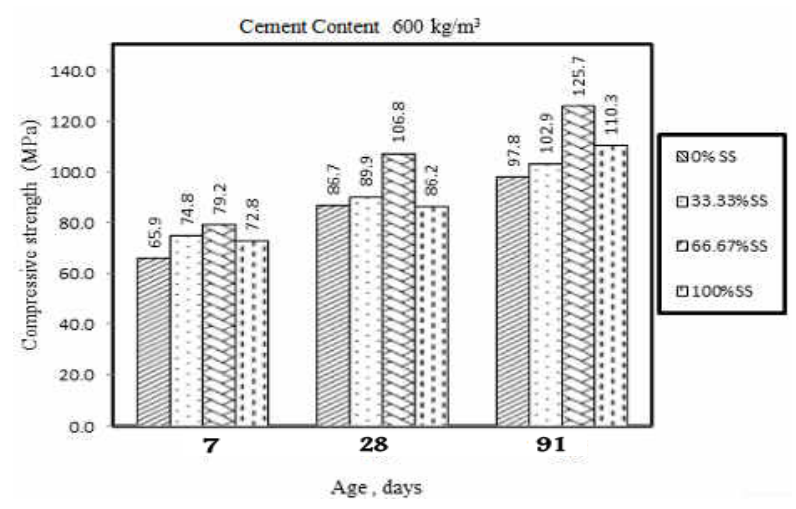

c) Mixes of $20 \%$ Silica Fume

Fig. 5. Effect of EAFSS Content in Mixes of Cement Content $600 \mathrm{~kg} / \mathrm{m}^{3}$ on the Compressive Strength

\subsubsection{Effect of cement content}

Tables (11) and (12) illustrate the effect of cement content of the similar concrete mixes with and without silica fume on the compressive strengths at different ages. In general, as expected, increasing the cement content increased the compressive strength. In mixes without EAFSS or silica fume, increasing the cement content from $350 \mathrm{~kg} / \mathrm{m}^{3}$ to $600 \mathrm{~kg} / \mathrm{m}^{3}$ increased the compressive strength after 91 days from 53.5 MPa in mix M5.1 to $88.9 \mathrm{MPa}$ in mix M1.4. This means that, the using of cement content equals $600 \mathrm{~kg} / \mathrm{m}^{3}$ instead of $350 \mathrm{~kg} / \mathrm{m}^{3}$ led to an increase in the compressive strength equal $66.2 \%$. In addition, the enhancement in the compressive strength due to the increase in cement content for mixes with $20 \%$ silica fume increased due to the pozzolanic reaction of the used silica fume. Increasing the cement content from $350 \mathrm{~kg} / \mathrm{m}^{3}$ to $600 \mathrm{~kg} / \mathrm{m}^{3}$ increased the compressive strength from 57.8 MPa in mix M5.2 to 97.8 MPa in mix M1.6 (69.2\%). On the other hand, increasing the cement contents in mixes of EAFSS coarse aggregates showed a high increase in the compressive strength of the studied concrete mixes, especially at later ages. The increase of the cement content from $450 \mathrm{~kg} / \mathrm{m}^{3}$ to $600 \mathrm{~kg} / \mathrm{m}^{3}$ (with $0 \%$ silica fume) increased the compressive strength after 91 days by about $18.0 \%, 47.4 \%$ and $41.3 \%$ in mixes possessed groups M1, M2, M3 and M4, respectively. The same trend was also observed in mixes of silica fume. This 
means that, the mixes of $66.67 \%$ EAFSS coarse aggregate (group M3) achieved the highest enhancement in compressive strength due to the increase in the cement content.

\subsubsection{Effect of silica fume percentage}

The effects of using silica fume (SF) as additions to cement on the compressive strengths of the similar mixes at different ages are shown in Table (11). In general, increasing the percentage of silica fume as addition to the cement content (up to 20\%) increased the compressive strength, especially at later ages. This is due to the well-known pozzolanic reaction of the silica fume. This observation was obtained for mixes with and without EAFSS coarse aggregate and for the used two cement contents $\left(450 \mathrm{~kg} / \mathrm{m}^{3}\right.$ and $\left.600 \mathrm{~kg} / \mathrm{m}^{3}\right)$. The effect of silica fume percentage was more obvious in groups M3 and M4, see Table (11). Moreover, in mixes of EAFSS fine and coarse aggregate, using of $20 \%$ SF caused a very high increase in the concrete compressive strength, see Table (12). This can be attributed to the increase in the homogeneity of the concrete mix which substitutes the absence of sand.

\subsubsection{Effect of using of EAFSS fine aggregate with the EAFSS coarse aggregate.}

Table (12) shows the results of compressive strength tests of mixes M5.1, M5.2, M6.1, M6.2, M7.1 and M7.2 at age of 7, 28 and 91 days, which possessed cement content equals $350 \mathrm{~kg} / \mathrm{m}^{3}$ for groups M5 and M6 and $450 \mathrm{~kg} / \mathrm{m}^{3}$ for group M7 with percentages of silica fume equal $0 \%$ and $20 \%$. The EAFSS coarse and fine aggregate with replacement percentages $0 \%$ and $100 \%$ were used in mixes of groups M6 and M7.

Using of EAFSS fine and coarse aggregate decreased the compressive strength of the studied mixes at all ages. Results of group M6 were lower than those of group M5, especially in mixes without silica fume due to the absence of homogeneity of the concrete mix. Also, if mixes of group M7 (M7.1 and M7.2) are compared with mixes of group M1 (M1.1 and M1.3) in Table (11), the bad effect of using both EAFSS fine and coarse aggregates on the compressive strength will be established. Moreover, comparisons between mixes M7.1, M7.2 and mixes M4.1, M4.3 established that using of EAFSS fine aggregate is the reason of the occurred lack in the concrete compression strength. The lack in the homogeneity of the concrete mixes caused large voids in concrete which in turn decreased its compressive strength. Despite of this lack in the compressive strength, high strength concrete still can be obtained in mixes of EAFSS fine aggregate when using silica fume with a percentage of $20 \%$ with cement content of $450 \mathrm{~kg} / \mathrm{m}^{3}$, (the compressive strength of M7.2 after 91 days recorded $76.6 \mathrm{MPa}$ ).

\section{Table 12.}

Presented the compressive strengths of the test concrete mixtures of groups M5, M6 and M7 at ages 7, 28 and 91 days.

\begin{tabular}{|c|c|c|c|c|c|c|c|c|c|}
\hline \multirow{2}{*}{ Group } & \multirow{2}{*}{ Mix No } & \multirow{2}{*}{$\begin{array}{c}\text { Cement } \\
\text { Content } \\
\left(\mathbf{k g} / \mathrm{m}^{3}\right)\end{array}$} & \multirow{2}{*}{$\begin{array}{c}\text { SF } \\
(\%)\end{array}$} & \multicolumn{2}{|c|}{ SS $(\%)$} & \multirow{2}{*}{$\begin{array}{l}\text { Weight } \\
\text { Volume* } \\
\left(\mathrm{g} / \mathrm{cm}^{3}\right)\end{array}$} & \multicolumn{3}{|c|}{ Compressive Strength $^{* *}\left(\mathrm{~N} / \mathrm{mm}^{2}\right)$} \\
\hline & & & & S.C.A & S.F.A & & 7 Days & 28 Days & 91 Days \\
\hline \multirow{2}{*}{ M5 } & M5.1 & 350 & 0 & 0 & \multirow{2}{*}{0} & 2.29 & 44.7 & 49.6 & 53.5 \\
\hline & M5.2 & 350 & 20 & 0 & & 2.31 & 50.3 & 53.1 & 57.8 \\
\hline \multirow{2}{*}{ M6 } & M6.1 & 350 & 0 & 100 & \multirow{2}{*}{100} & 2.49 & 8.5 & 9.1 & 11.6 \\
\hline & M6.2 & 350 & 20 & 100 & & 2.45 & 33.9 & 35.3 & 40.2 \\
\hline \multirow{2}{*}{ M7 } & M7.1 & 450 & 0 & 100 & \multirow{2}{*}{100} & 2.42 & 26.4 & 28.2 & 32.7 \\
\hline & M7.2 & 450 & 20 & 100 & & 2.73 & 67.9 & 70.4 & 76.6 \\
\hline
\end{tabular}

* Volume weight is the average of the test nine cubes (at ages 7, 28 and 91 days).

** Compressive strengths are the average of the result of testing of three cubes at the same age 
Asmaa Mohamed Nageib Abdel Hamid et al., Properties of high strength concrete containing .........

\subsubsection{Indirect tensile strength}

\subsubsection{Effect of replacement percentage of EAFSS coarse aggregate}

Figure (6-a) shows a comparison between the indirect tensile strength at 91 days of mixes which possessed cement contents equal $450 \mathrm{~kg} / \mathrm{m}^{3}$ and $600 \mathrm{~kg} / \mathrm{m}^{3}$ without silica fume. The replacement percentages of EAFSS coarse aggregate in these mixes equal $0 \%$, $33.33 \%, 66.67 \%$ and $100 \%$. In mixes of cement contents $450 \mathrm{~kg} / \mathrm{m}^{3}$, it can be observed that the concrete mix M2.1 which possessed replacement ratio of $33.33 \%$ recorded the highest indirect tensile strength after 91 days. However, as illustrated in Table (13), the indirect tensile strength for these mixes ranged from 4.1 MPa for mixes M1.1 and M4.1 (0\% and $100 \%$ EAFSS) to $4.8 \mathrm{MPa}$ for mix M2.1 (33.33\% EAFSS), i.e. using of 33.33\% EAFSS as a replacement of the natural coarse aggregates led to an increase in the indirect tensile strength equals $17.1 \%$. On the other hand, as illustrated in this figure, the concrete mix M3.4 which possessed replacement ratio of $66.67 \%$ recorded the highest indirect tensile strength in mixes of cement content equals $600 \mathrm{~kg} / \mathrm{m}^{3}$ without SF ( $6.2 \mathrm{MPa}$ ). However, as illustrated in Table (13), the indirect tensile strength after 91 days for these mixes possessed EAFSS coarse aggregate ranged from 5.3 MPa for mix M4.4 (100\% EAFSS) to 6.2 MPa for mix M3.4 (66.67\% EAFSS). The control mix M1.4 (0\% EAFSS) recorded indirect tensile strength equals $4.4 \mathrm{MPa}$ after 91 days. This means that, the using of $66.67 \%$ EAFSS as a replacement of the natural coarse aggregates led to an increase in the indirect tensile strength equals $40.9 \%$ at cement content of $600 \mathrm{~kg} / \mathrm{m}^{3}$ without silica fume. Similarly, Figures (6-b) and (6-c) show the effect of EAFSS content on the indirect tensile strength of mixtures of cement content equal $450 \mathrm{~kg} / \mathrm{m}^{3}, 600 \mathrm{~kg} / \mathrm{m}^{3}$ and possessed silica fume with ratios $10 \%$ and $20 \%$ as addition to cement, respectively. As illustrated in these Figures and Table (13), the indirect tensile strength of mixes possessed $33.33 \%$ of EAFSS recorded a significant increase in the indirect tensile strength at cement content of 450 $\mathrm{kg} / \mathrm{m}^{3}$ if compared to the control mixes (M1.2 and M1.3). On the other hand, the indirect tensile strength of mixes of 66.67\% EAFSS (mixes M3.5 and M3.6) recorded the highest indirect tensile strength at cement content of $600 \mathrm{~kg} / \mathrm{m}^{3}$. The indirect tensile strength for mixes M3.5 and M3.6 were 6.7 MPa and 6.9 MPa, respectively, see Table (13). This means that, the increase in the indirect tensile strength for mixes of $66.67 \%$ EAFSS as coarse aggregate reached $32.7 \%$ after 91 days in mix M3.6 if compared to the control mix M1.6.

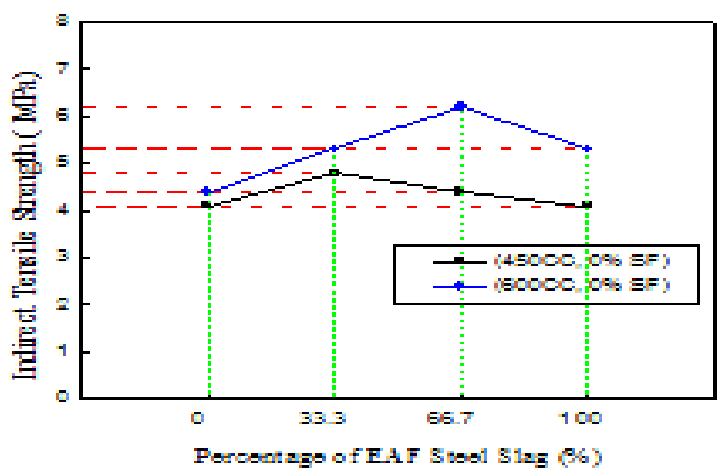

a) Mixes of $0 \% \mathrm{SF}$ 


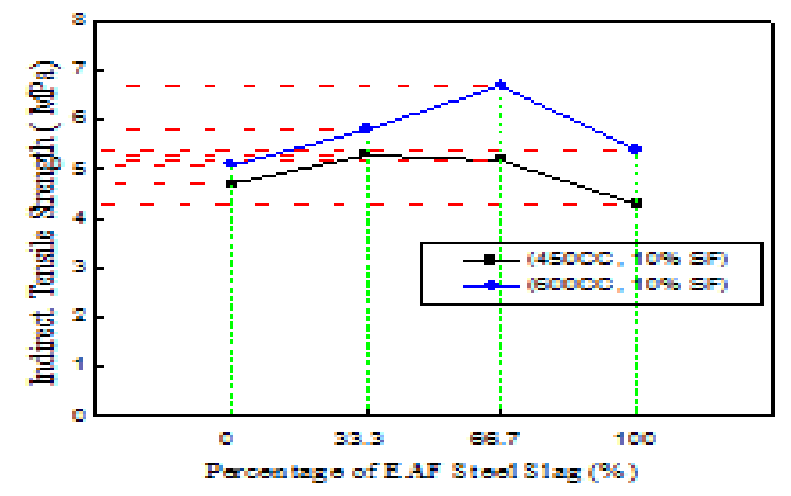

b) Mixes of $10 \% \mathrm{SF}$

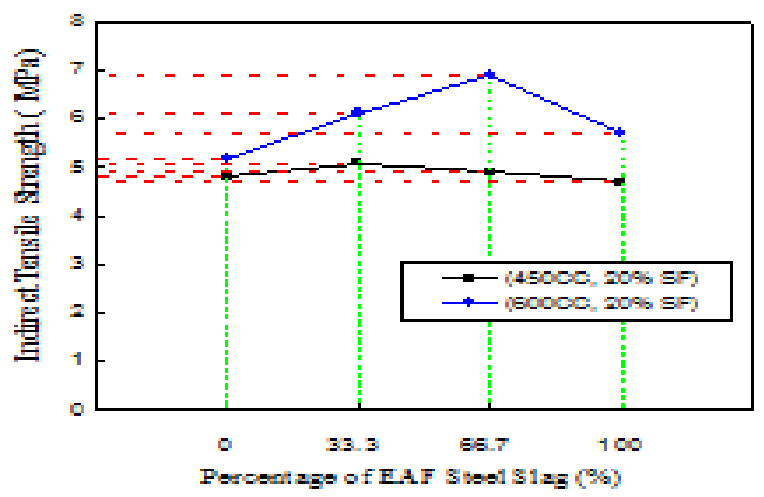

c) Mixes of $20 \% \mathrm{SF}$

Fig. 6. (a, b, c) Relationship between Indirect Tensile Strength and Percentage of Replacement of EAFSS Coarse Aggregate at 91 Days

\subsubsection{Effect of cement content}

In general, as indicated from Tables (13) and (14), increasing the cement content increased the indirect tensile strength at 91 days. In mixes without EAFSS or silica fume, increasing the cement content from $350 \mathrm{~kg} / \mathrm{m}^{3}$ to $600 \mathrm{~kg} / \mathrm{m}^{3}$ increased the indirect tensile strength after 91 days from $3.7 \mathrm{MPa}$ in mix M5.1 to $4.4 \mathrm{MPa}$ in mix M1.4. This means that, using of cement content equals $600 \mathrm{~kg} / \mathrm{m}^{3}$ instead of $350 \mathrm{~kg} / \mathrm{m}^{3}$ led to an increase in the indirect tensile strength equals $18.9 \%$. In addition, the enhancement in the indirect tensile strength for mixes with $20 \%$ silica fume due to the increase in cement content achieved approximately the same enhancement percentage. Increasing the cement content from 350 $\mathrm{kg} / \mathrm{m}^{3}$ to $600 \mathrm{~kg} / \mathrm{m}^{3}$ increased the indirect tensile strength from 4.4 MPa in mix M5.2 to 5.2 MPa in mix M1.6 (18.2\%). On the other hand, increasing the cement contents in mixes of EAFSS coarse aggregates showed a higher increase in the indirect tensile strength of the studied concrete mixes. The increase in the cement content from $450 \mathrm{~kg} / \mathrm{m}^{3}$ to $600 \mathrm{~kg} / \mathrm{m}^{3}$ (with $0 \%$ silica fume) increased the indirect tensile strength about by $7.3 \%, 12.5 \%, 40.9 \%$ and $29.3 \%$ in mixes of groups M1, M2, M3 and M4, respectively. The same trend was also observed in mixes possessed silica fume. This means that, mixes of $66.67 \%$ EAFSS coarse aggregate achieved the highest enhancement in the indirect tensile strength due to the increase in the cement content. 
Asmaa Mohamed Nageib Abdel Hamid et al., Properties of high strength concrete containing .........

\subsubsection{Effect of silica fume percentage}

The effects of using silica fume (SF) as addition to cement on the indirect tensile strengths of the similar mixes at 91 days are shown in Table (13). In general, increasing the percentage of silica fume as addition to the cement content (up to 20\%) increased the indirect tensile strength. As mentioned before, this is due to the pozzolanic reaction of the silica fume. This observation was obtained for mixes with and without EAFSS coarse aggregate and for the used two cement contents $(450 \mathrm{~kg} / \mathrm{m} 3$ and $600 \mathrm{~kg} / \mathrm{m} 3)$. On the other hand, in mixes of EAFSS fine and coarse aggregate using of $20 \%$ SF caused a very high increase in the concrete indirect tensile strength, see Table (14). This can be attributed to the increase in the past volume which substitutes the absence of sand.

\subsubsection{Effect of using of EAFSS fine aggregate with the EAFSS coarse aggregate}

The results of indirect tensile strength tests of mixes of groups M5, M6 and M7 at 91 days are presented in Table (14). Using of EAFSS fine and coarse aggregate decreased the indirect tensile strength of the studied mixes of cement content equals $350 \mathrm{~kg} / \mathrm{m}^{3}$. Results of mixes of group M6 were lower than the corresponding values of group M5. The indirect tensile strength of mixes without silica fume decreased from 3.7 MPa in mix M5.1 to 2.8 $\mathrm{MPa}$ in mix M6.1. Also, the indirect tensile strength decreased for mixes of silica fume from 4.4 MPa in mix M5.2 to 3.5 MPa in mix M6.2. On the contrary, if mixes of group M7 (M7.1 and M7.2) are compared with mixes of group M1 (M1.1 and M1.3) in Table (13), the better effect of using both EAFSS fine and coarse aggregates can be remarked in mixes possessed silica fume. Using of EAFSS fine and coarse aggregate increased the indirect tensile strength from $4.8 \mathrm{MPa}$ in M1.3 to $5.6 \mathrm{MPa}$ in M7.2. In addition, comparison between mixes M7.2 and M4.3 established that using of EAFSS fine aggregate is the reason of the occurred increased in the concrete indirect tensile strength. On the other hand, comparisons between the results of M7.1, M1.1 and M4.1 did not demonstrate a notable change in the indirect tensile strength when using EAFSS fine aggregate in mixes without silica fume.

Table 13.

Results of indirect tensile strength, flexural strength and modulus of elasticity for EAFSS coarse aggregates mixes after 91 days.

\begin{tabular}{|c|c|c|c|c|c|c|c|}
\hline Group & Mix No & $\begin{array}{l}\text { Cement } \\
\text { Content } \\
\left(\mathrm{kg} / \mathrm{m}^{3}\right)\end{array}$ & SF \% & S.S.C.A & $\begin{array}{c}\text { Indirect } \\
\text { Tensile } \\
\text { Strength } \\
(\mathrm{MPa}) \\
\end{array}$ & $\begin{array}{c}\text { Flexural } \\
\text { Strength } \\
(\mathrm{MPa})\end{array}$ & $\begin{array}{c}\text { Modulus of } \\
\text { Elasticity } \\
\text { (GPa) }\end{array}$ \\
\hline \multirow{6}{*}{ M1 } & M1.1 & 450 & 0 & \multirow{6}{*}{0} & 4.1 & 10.9 & 32.8 \\
\hline & M1.2 & 450 & 10 & & 4.7 & 13.6 & 35.9 \\
\hline & M1.3 & 450 & 20 & & 4.8 & 13.6 & 37.1 \\
\hline & M1.4 & 600 & 0 & & 4.4 & 13.1 & 35.3 \\
\hline & M1.5 & 600 & 10 & & 5.1 & 13.9 & 37.1 \\
\hline & M1.6 & 600 & 20 & & 5.2 & 14.0 & 39.5 \\
\hline \multirow{5}{*}{ M2 } & M2.1 & 450 & 0 & \multirow{5}{*}{33.33} & 4.8 & 11.5 & 34.9 \\
\hline & M2.2 & 450 & 10 & & 5.3 & 14.0 & 36.7 \\
\hline & M2.3 & 450 & 20 & & 5.1 & 13.8 & 39.6 \\
\hline & M2.4 & 600 & 0 & & 5.4 & 13.4 & 38.7 \\
\hline & M2.5 & 600 & 10 & & 5.8 & 15.0 & 39.7 \\
\hline
\end{tabular}


JES, Assiut University, Faculty of Engineering, Vol. 42, No. 3, May2014, pp. 582-608

\begin{tabular}{|c|c|c|c|c|c|c|c|}
\hline Group & Mix No & $\begin{array}{l}\text { Cement } \\
\text { Content } \\
\left(\mathrm{kg} / \mathrm{m}^{3}\right)\end{array}$ & SF \% & S.S.C.A & $\begin{array}{c}\text { Indirect } \\
\text { Tensile } \\
\text { Strength } \\
(\mathrm{MPa})\end{array}$ & $\begin{array}{c}\text { Flexural } \\
\text { Strength } \\
(\mathrm{MPa})\end{array}$ & $\begin{array}{l}\text { Modulus of } \\
\text { Elasticity } \\
\quad(\mathrm{GPa})\end{array}$ \\
\hline & M2.6 & 600 & 20 & & 6.1 & 15.2 & 42.4 \\
\hline \multirow{6}{*}{ M3 } & M3.1 & 450 & 0 & \multirow{6}{*}{66.67} & 4.4 & 11.4 & 34.2 \\
\hline & M3.2 & 450 & 10 & & 5.2 & 13.7 & 36.1 \\
\hline & M3.3 & 450 & 20 & & 4.9 & 14.7 & 38.1 \\
\hline & M3.4 & 600 & 0 & & 6.2 & 14.1 & 40.7 \\
\hline & M3.5 & 600 & 10 & & 6.7 & 15.8 & 42.1 \\
\hline & M3.6 & 600 & 20 & & 6.9 & 15.8 & 45.2 \\
\hline \multirow{6}{*}{ M4 } & M4.1 & 450 & 0 & \multirow{6}{*}{100} & 4.1 & 9.6 & 33.0 \\
\hline & M4.2 & 450 & 10 & & 4.3 & 11.3 & 35.2 \\
\hline & M4.3 & 450 & 20 & & 4.7 & 12.8 & 36.8 \\
\hline & M4.4 & 600 & 0 & & 5.3 & 12.2 & 37.0 \\
\hline & M4.5 & 600 & 10 & & 5.4 & 12.4 & 37.9 \\
\hline & M4.6 & 600 & 20 & & 5.7 & 13.6 & 40.1 \\
\hline
\end{tabular}

Table 14.

Results of indirect tensile strength, flexural strength and modulus of elasticity for mixes of groups M5, M6 and M7.

\begin{tabular}{|c|c|c|c|c|c|c|c|c|}
\hline \multirow[b]{2}{*}{ Group } & \multirow[b]{2}{*}{$\begin{array}{c}\text { Mix } \\
\text { No }\end{array}$} & \multirow{2}{*}{$\begin{array}{l}\text { Cement } \\
\text { Content } \\
(\mathrm{kg} / \mathrm{m3})\end{array}$} & \multirow[b]{2}{*}{$\begin{array}{l}\text { SF } \\
(\%)\end{array}$} & \multicolumn{2}{|c|}{ SS $(\%)$} & \multirow{2}{*}{$\begin{array}{c}\text { Indirect } \\
\text { Tensile } \\
\text { Strength } \\
\text { (MPa) }\end{array}$} & \multirow{2}{*}{$\begin{array}{c}\text { Flexural } \\
\text { Strength } \\
\text { (MPa) }\end{array}$} & \multirow{2}{*}{$\begin{array}{c}\text { Modulus } \\
\text { of } \\
\text { Elasticity } \\
\text { (GPa) }\end{array}$} \\
\hline & & & & S.C.A & S.F.A & & & \\
\hline \multirow{2}{*}{ M5 } & M5.1 & 350 & 0 & 0 & \multirow{2}{*}{0} & 3.7 & 7.2 & 23.5 \\
\hline & M5.2 & 350 & 20 & 0 & & 4.4 & 8.4 & 30.3 \\
\hline \multirow{2}{*}{ M6 } & M6.1 & 350 & 0 & 100 & \multirow{2}{*}{100} & 2.8 & 3.9 & 13.3 \\
\hline & M6.2 & 350 & 20 & 100 & & 3.5 & 7.3 & 17.5 \\
\hline \multirow{2}{*}{ M7 } & M7.1 & 450 & 0 & 100 & \multirow{2}{*}{100} & 4.0 & 7.6 & 17.8 \\
\hline & M7.2 & 450 & 20 & 100 & & 5.6 & 12.5 & 27.2 \\
\hline
\end{tabular}

\subsubsection{Flexural strength}

\subsubsection{Effect of replacement percentage of EAFSS coarse aggregate}

Figure (7-a) shows a comparison between the flexural strength after 91 days of mixes which possessed cement contents equal $450 \mathrm{~kg} / \mathrm{m}^{3}$ and $600 \mathrm{~kg} / \mathrm{m}^{3}$ without silica fume. The replacement percentages of EAFSS coarse aggregate in these mix equal $0 \%, 33.33 \%$, $66.67 \%$ and $100 \%$. In mixes of cement contents $450 \mathrm{~kg} / \mathrm{m}^{3}$, it can be observed that the concrete mix M2.1 and M3.1 which possessed a replacement ratio of $33.33 \%$ and $66.67 \%$ recorded increase in the flexural strength after 91 days. However, as illustrated in Table (13), the flexural strength for these mixes ranged from 9.6 MPa for mixes M4.1 (100\% EAFSS) to 11.5 MPa for mix M2.1 (33.33\% EAFSS), while the flexural strength of the control mix M1.1 was $10.9 \mathrm{MPa}$, i.e. using of 33.33\%EAFSS as a replacement of the natural coarse aggregates led to an increase in the flexural strength equals $5.5 \%$ at cement content equals $450 \mathrm{~kg} / \mathrm{m}^{3}$. On the other hand, as illustrated in this figure, the concrete mix M3.4 which possessed replacement ratio of $66.67 \%$ recorded the highest flexural strength in mixes of cement content equals $600 \mathrm{~kg} / \mathrm{m}^{3}$ without SF. However, as illustrated in Table (13), the flexural strength after 91 days for these mixes possessed EAFSS coarse aggregate ranged from 12.2 MPa for mix M4.4 (100\% EAFSS) to 14.1 MPa for mix M3.4 (66.67\% EAFSS). 
The control mix M1.4 (0\% EAFSS) recorded a flexural strength equals $13.1 \mathrm{MPa}$ after 91 days. This means that, the using of $66.67 \%$ EAFSS as a replacement of the natural coarse aggregates led to an increase in the flexural strength equals $7.6 \%$ at cement content of 600 $\mathrm{kg} / \mathrm{m}^{3}$ (without SF). Similarly, Figures (7-b) and (7-c) show the effect of EAFSS content on the flexural strength of mixtures of cement content equal $450 \mathrm{~kg} / \mathrm{m}^{3}, 600 \mathrm{~kg} / \mathrm{m}^{3}$ and possessed silica fume with ratios $10 \%$ and $20 \%$ as addition to cement, respectively. As illustrated in these Figures and Table (13), the flexural strength of mixes possessed 33.33\% of EAFSS recorded a significant increase in the flexural strength at cement content of 450 $\mathrm{kg} / \mathrm{m}^{3}$ if compared to the control mixes (M1.2 and M1.3). On the other hand, the flexural strength for mixes of 66.67\% EAFSS (mixes M3.5 and M3.6) recorded the highest flexural strength after 91 days. The flexural strength for mixes M3.5 and M3.6 were equals (15.8 $\mathrm{MPa}$ ), see Table (13). This means that, the increase in the flexural strength for mixes of $33.33 \%$ and $66.67 \%$ EAFSS as coarse aggregate reached $(7.9 \%, 8.6 \%)$ and $(13.71 \%, 12.9 \%)$ after 91days if compared to the control mixes M1.5 and M1.6, respectively.

\subsubsection{Effect of cement content}

In general, as indicated from Tables (13) and (14), increasing the cement content increased the flexural strength at 91 days. In mixes without EAFSS or silica fume, increasing the cement content from $350 \mathrm{~kg} / \mathrm{m}^{3}$ to $600 \mathrm{~kg} / \mathrm{m}^{3}$ increased the flexural strength after 91 days from 7.2 MPa in mix M5.1 to $13.1 \mathrm{MPa}$ in mix M1.4. This means that, the using of cement content equals $600 \mathrm{~kg} / \mathrm{m}^{3}$ instead of $350 \mathrm{~kg} / \mathrm{m}^{3}$ led to an increase in the flexural strength equals $81.9 \%$. In addition, the enhancement in the flexural strength for mixes with $20 \%$ silica fume due to the increase in cement content achieved approximate the same enhancement percentage. Increasing the cement content from $350 \mathrm{~kg} / \mathrm{m}^{3}$ to 600 $\mathrm{kg} / \mathrm{m}^{3}$ increased the flexural strength from 8.4 MPa in mix M5.2 to 14.0 MPa in mix M1.6 $(66.7 \%)$. On the other hand, increasing the cement contents in mixes of EAFSS coarse aggregates showed a higher increase in the flexural strength of the studied concrete mixes.

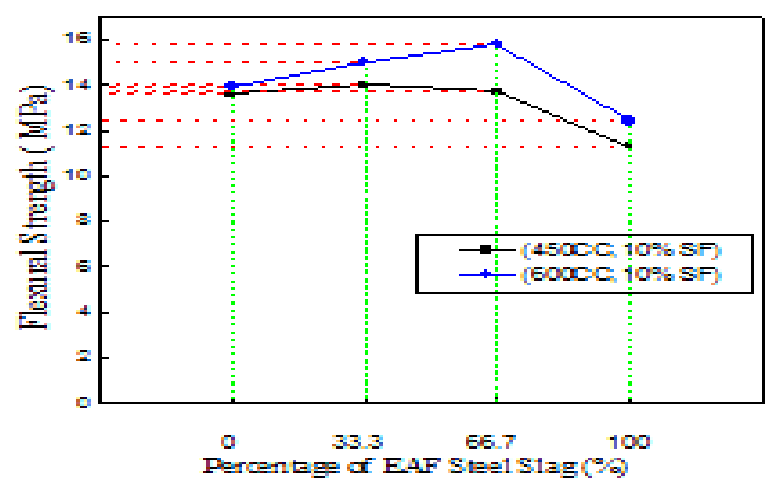

a) Mixes of $0 \% \mathrm{SF}$ 


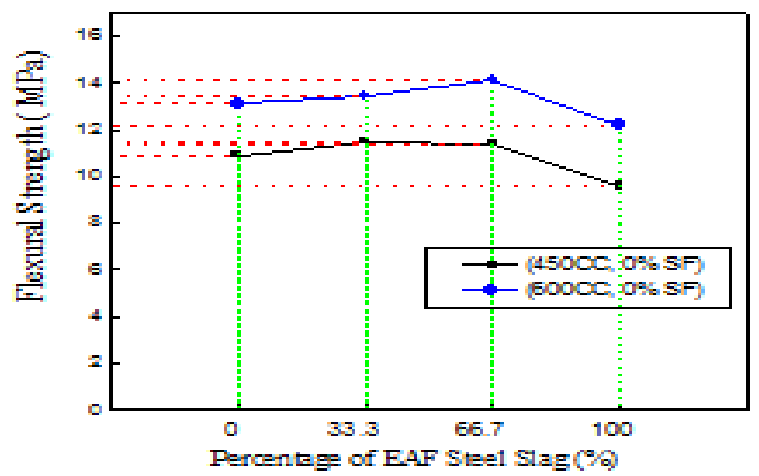

b) Mixes of $10 \% \mathrm{SF}$

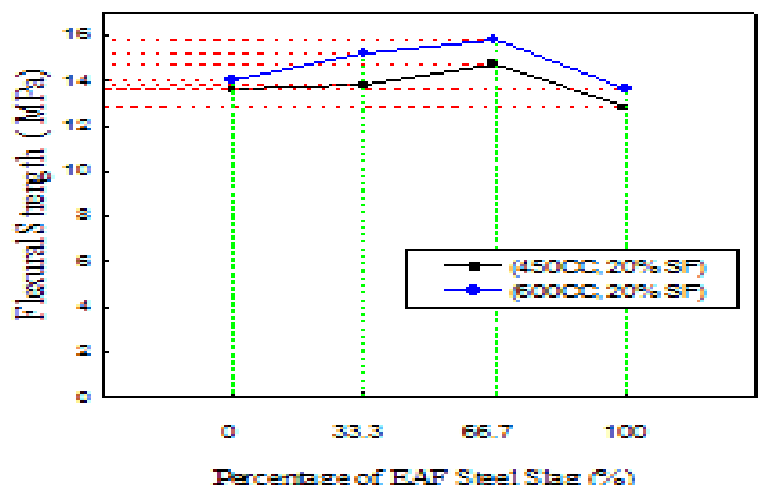

c) Mixes of $20 \% \mathrm{SF}$

Fig. 7. (a, b, c) Relationship between Flexural Strength and Percentage of Replacement of (SSCA) at 91 Days

The increase in the cement content from $450 \mathrm{~kg} / \mathrm{m}^{3}$ to $600 \mathrm{~kg} / \mathrm{m}^{3}$ (with $0 \%$ silica fume) increased the flexural strength about by $20.2 \%, 16.5 \%, 23.7 \%$ and $27.1 \%$ in mixes of groups M1, M2, M3 and M4, respectively. The same trend was also observed in mixes possessed silica fume. This means that, the mixes of $66.67 \%$ EAFSS aggregate achieved the highest enhancement in the flexural strength due to the increase in the cement content.

\subsubsection{Effect of silica fume percentage}

The effects of using silica fume (SF) as addition to cement on the flexural strengths of the similar mixes at 91 days are shown in Table (13). In general, increasing the percentage of silica fume as addition to the cement content (up to 20\%) increased the flexural strength. As mentioned before, this is due to the pozzolanic reaction of the silica fume. This observation was obtained for mixes with and without EAFSS coarse aggregate and for the used two cement contents $\left(450 \mathrm{~kg} / \mathrm{m}^{3}\right.$ and $\left.600 \mathrm{~kg} / \mathrm{m}^{3}\right)$. On the other hand, in mixes of EAFSS fine and coarse aggregate using of $20 \%$ SF caused a very high increase in the concrete flexural strength, see Table (14). This can be attributed to the increase in the past volume which substitutes the absence of sand. 
3.2.4.4. Effect of using of EAFSS fine aggregate with the EAFSS coarse aggregate

The results of flexural strength tests of mixes of groups M5, M6 and M7 at 91 days are presented in Table (14). Using of EAFSS fine and coarse aggregate decreased the flexural strength of the studied mixes of cement contents equal $350 \mathrm{~kg} / \mathrm{m}^{3}$ and $450 \mathrm{~kg} / \mathrm{m}^{3}$. Results of mixes of group M6 were lower than the corresponding values of group M5. The flexural strength of mixes without silica fume decreased from 7.2 MPa in mix M5.1 to 3.9 MPa in mix M6.1. Also, the flexural strength decreased for mixes of silica fume from 8.4 MPa in mix M5.2 to 7.3 MPa in mix M6.2. On the other hand, if mixes of group M7 (M7.1 and M7.2) are compared with mixes of group M1 (M1.1 and M1.3) in Table (13), the better effect of using natural aggregates can be remarked in mixes with and without silica fume. Using of EAFSS fine and coarse aggregate decreased the flexural strength from 13.6 MPa in M1.3 to $12.5 \mathrm{MPa}$ in M7.2. In addition, comparison between mixes M7.2 and M4.3 established that using of EAFSS fine aggregate is the reason of the occurred decreased in the concrete flexural strength.

\subsubsection{Modulus of Elasticity}

\subsubsection{Effect of replacement percentage of EAFSS coarse aggregate}

Figure (8-a) shows a comparison between the modulus of elasticity at 91 days of mixes which possessed cement contents equal $450 \mathrm{~kg} / \mathrm{m}^{3}$ and $600 \mathrm{~kg} / \mathrm{m}^{3}$ without silica fume. The replacement percentages of EAFSS coarse aggregate in these mix equal $0 \%, 33.33 \%$, $66.67 \%$ and $100 \%$. In mixes of cement contents $450 \mathrm{~kg} / \mathrm{m}^{3}$, it can be observed that the concrete mix M2.1 which possessed a replacement ratio of $33.33 \%$ recorded the highest modulus of elasticity after 91 days. However, as illustrated in Table (13), the modulus of elasticity for these mixes ranged from $33.0 \mathrm{GPa}$ for mixes M4.1 (100\% EAFSS) to $34.9 \mathrm{GPa}$ for mix M2.1 (33.33\% EAFSS). On the other hand, mix M1.1 (0\%EAFSS) recorded modulus of elasticity equals $32.8 \mathrm{GPa}$ after 91 days; i.e. using of $33.33 \%$ EAFSS as a replacement of the natural coarse aggregates led to an increase in the modulus of elasticity equals $6.4 \%$. On the other hand, as illustrated in this figure, the concrete mix M3.4 which possessed replacement ratio of $66.67 \%$ recorded the highest modulus of elasticity in mixes of cement content equals $600 \mathrm{~kg} / \mathrm{m}^{3}$ without SF (14.1MPa). However, as illustrated in Table (13), the modulus of elasticity after 91 days for the mixes possessed EAFSS coarse aggregate ranged from 37.0 GPa for mix M4.4 (100\% EAFSS) to $40.7 \mathrm{GPa}$ for mix M3.4 (66.67\% EAFSS). The control mix M1.4 (0\% EAFSS) recorded a modulus of elasticity equals 35.3 GPa after 91 days. This means that, the using of $66.67 \%$ EAFSS as a replacement of the natural coarse aggregates led to an increase in the modulus of elasticity equals $4.8 \%$ at cement content of $600 \mathrm{~kg} / \mathrm{m}^{3}$ (without SF). Similarly, Figures (8-b) and (8-c) show the effect of EAFSS content on the modulus of elasticity of mixtures of cement contents equal 450 $\mathrm{kg} / \mathrm{m}^{3}, 600 \mathrm{~kg} / \mathrm{m}^{3}$ and possessed silica fume with ratios $10 \%$ and $20 \%$ as addition to cement, respectively. As illustrated in these Figures and Table (13), the modulus of elasticity of mixes possessed $33.33 \%$ of EAFSS recorded a significant increase in the modulus of elasticity at cement content of $450 \mathrm{~kg} / \mathrm{m}^{3}$ if compared to the control mixes (M1.2 and M1.3). On the other hand, the modulus of elasticity of mixes of 66.67\% EAFSS (mixes M3.5 and M3.6) recorded the highest modulus of elasticity at cement content of $600 \mathrm{~kg} / \mathrm{m}^{3}$. The modulus of elasticity for mixes M3.5 and M3.6 were (42.1 GPa) and (45.2 GPa), respectively, see Table (13). This means that, the increase in the modulus of elasticity for mixes of $33.33 \%$ and $66.67 \%$ EAFSS as coarse aggregate reached $(7 \%, 7.3 \%)$ and $(13.5 \%$, 
$14.4 \%$ ) after 91 days if compared to the control mixes M1.5 and M1.6, respectively.

\subsubsection{Effect of cement content}

In general, as indicated from Tables (13) and (14), increasing the cement content increased the modulus of elasticity at 91 days. In mixes without EAFSS or silica fume, increasing the cement content from $350 \mathrm{~kg} / \mathrm{m}^{3}$ to $600 \mathrm{~kg} / \mathrm{m}^{3}$ increased the modulus of elasticity after 91 days from $18.5 \mathrm{GPa}$ in mix M5.1 to $35.3 \mathrm{GPa}$ in mix M1.4. This means that, the using of cement content equals $600 \mathrm{~kg} / \mathrm{m}^{3}$ instead of $350 \mathrm{~kg} / \mathrm{m}^{3}$ led to an increase in the modulus of elasticity equal $90.8 \%$. In addition, the enhancement in the modulus of elasticity for mixes with $20 \%$ silica fume due to the increase in cement content achieved approximate the same enhancement percentage. Increasing the cement content from 350 $\mathrm{kg} / \mathrm{m}^{3}$ to $600 \mathrm{~kg} / \mathrm{m}^{3}$ increased the modulus of elasticity from $20.3 \mathrm{GPa}$ in mix M5.2 to 39.5 $\mathrm{GPa}$ in mix M1.6 (94.6\%). On the other hand, increasing the cement contents in mixes of EAFSS coarse aggregates showed a higher increase in the modulus of elasticity of the studied concrete mixes. The increase in the cement content from $450 \mathrm{~kg} / \mathrm{m}^{3}$ to $600 \mathrm{~kg} / \mathrm{m}^{3}$ (with $0 \%$ silica fume) to increased the modulus of elasticity about by $7.6 \%, 10.9 \%, 19.0 \%$ and $12.1 \%$ in mixes of groups M1, M2, M3 and M4, respectively. The same trend was also observed in mixes possessed silica fume. This means that, the mixes of $66.67 \%$ EAFSS aggregate achieved the highest enhancement in the modulus of elasticity due to the increase in the cement content.

\subsubsection{Effect of silica fume percentage}

The effects of using silica fume (SF) as addition to cement on the modulus of elasticity of the similar mixes at 91 days are shown in Table (13). In general, increasing the percentage of silica fume as addition to the cement content (up to 20\%) increased the modulus of elasticity. As mentioned before, this is due to the pozzolanic reaction of the silica fume. This observation was obtained for mixes with and without EAFSS coarse aggregate and for the used two cement contents $\left(450 \mathrm{~kg} / \mathrm{m}^{3}\right.$ and $\left.600 \mathrm{~kg} / \mathrm{m}^{3}\right)$. On the other hand, in mixes of EAFSS fine and coarse aggregate using of $20 \%$ SF caused a very high increase in the concrete modulus of elasticity, see Table (14). This can be attributed to the increase in the past volume which substitutes the absence of sand.

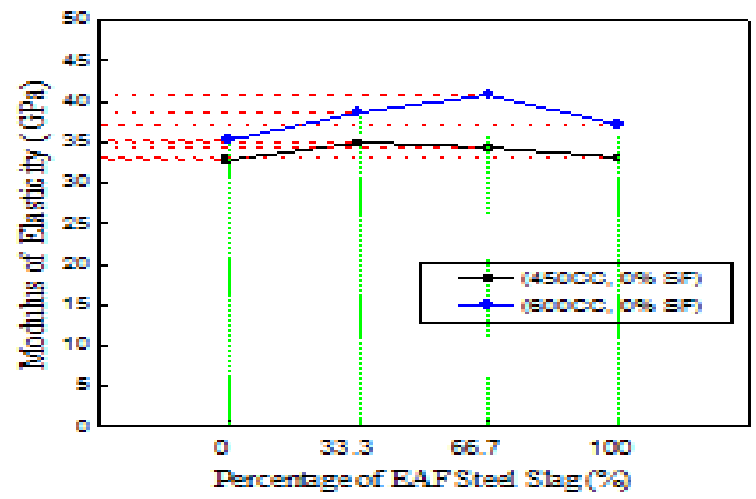

a) Mixes of $0 \% \mathrm{SF}$ 


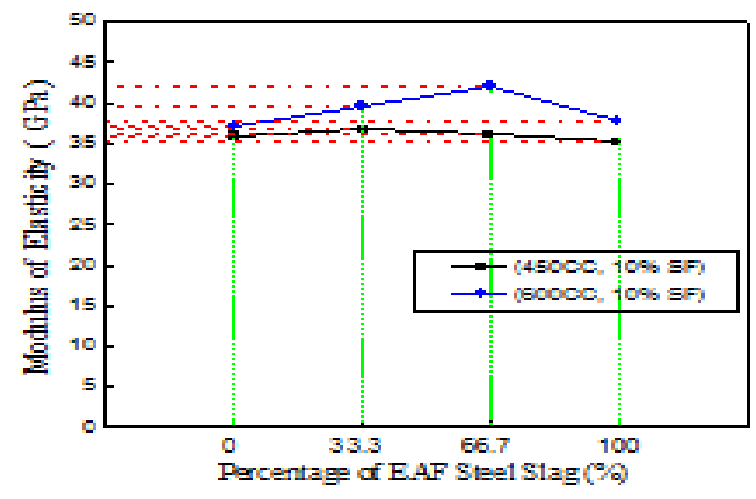

b) Mixes of $10 \% \mathrm{SF}$

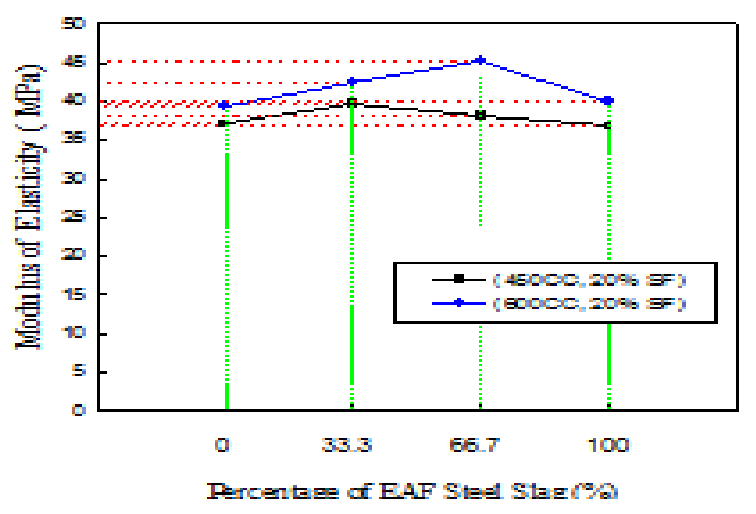

c) Mixes of $20 \% \mathrm{SF}$

Fig. 8. (a, b, c) Relationship between Modulus of Elasticity and Percentage of Replacement of EAFSS Coarse Aggregate at 91 Days

\subsubsection{Effect of using of EAFSS fine aggregate with the EAFSS coarse aggregate}

The results of modulus of elasticity tests of mixes of groups M5, M6 and M7 at 91 days are presented in Table (14). Using of EAFSS fine and coarse aggregate decreased the modulus of elasticity of the studied mixes of cement content equals $350 \mathrm{~kg} / \mathrm{m} 3$. Results of mixes of group M6 were lower than corresponding values of group M5. The modulus of elasticity of mixes without silica fume decreased from $18.5 \mathrm{GPa}$ in mix M5.1 to $13.3 \mathrm{GPa}$ in mix M6.1. Also, the modulus of elasticity decreased for mixes of silica fume from $20.3 \mathrm{GPa}$ in mix M5.2 to 17.5 GPa in mix M6.2. On the other hand, if mixes of group M7 (M7.1 and M7.2) are compared with mixes of group M1 (M1.1 and M1.3) in Table (13), the better effect of using natural aggregates can be remarked in mixes with and without silica fume. Using of EAFSS fine and coarse aggregate decreased the modulus of elasticity from $32.8 \mathrm{GPa}$ in M1.3 to 27.2 GPa in M7.2. In addition, comparison between mixes M7.2 and M4.3 established that using of EAFSS fine aggregate is the reason of the occurred decreased in the concrete modulus of elasticity. 


\subsubsection{Water permeability}

\subsubsection{Effect of replacement percentage of EAFSS coarse aggregate}

Permeability tests at age 91 days were conducted on samples of groups M1, M2, M3 and M4 to investigate the effect of percentage of EAFSS coarse aggregate on the coefficient of permeability. The concrete specimens were subjected to a hydrostatic water pressure of 30 bars for 24 hours. The water permeated through the test specimens is directly collected and measured in a graduated cylinder. Figure (9) shows the used apparatus for applying the hydrostatic water pressure.

Figures (10-a), (10-b) and (10-c) illustrate the effect of the percentage of replacement of EAFSS coarse aggregate for mixes of $0 \%, 10 \%$ and $20 \%$ silica fume, respectively on the permeability coefficient. As shown in these Figures, in general, increasing the replacement percentage of the used EAFSS coarse aggregate increased the impermeability of the concrete (decrease the permeability coefficient). This can be attributed to the better physical and mechanical properties of the EAFSS coarse aggregate if compared with the used natural coarse aggregate, refer to Tables (5) and (7). The reduction in the permeability coefficient reached about $50 \%$ of its original values when using EAFSS coarse aggregate in mixes of $0 \%$ silica fume.

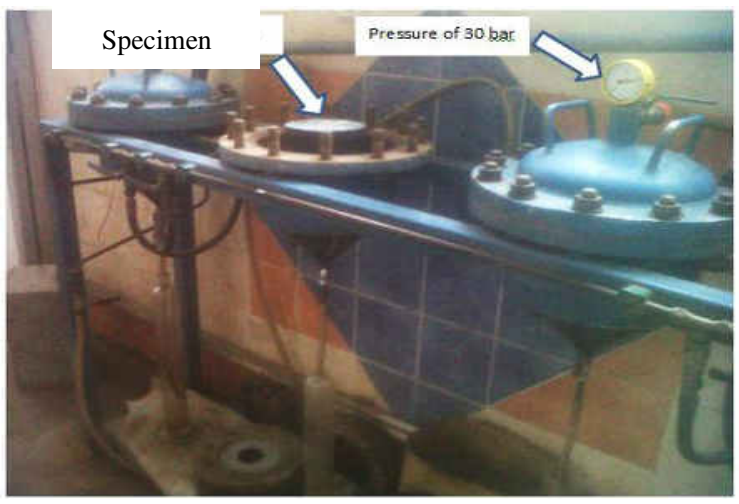

Fig. 9. The Water Permeability Apparatus

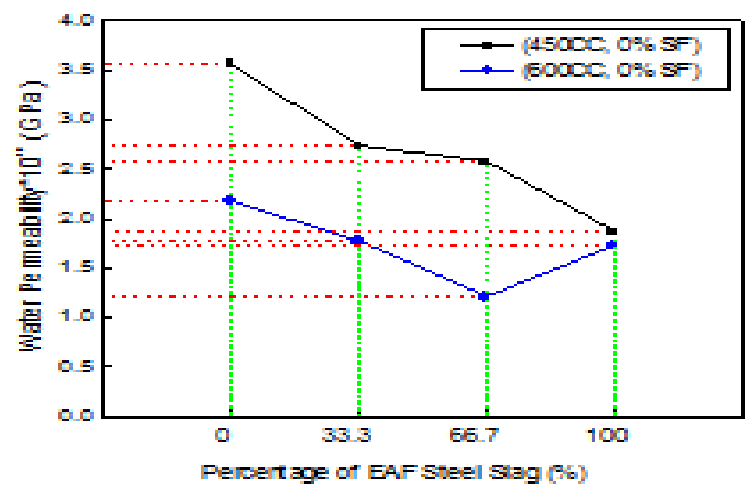

a) Mixes of $0 \% \mathrm{SF}$ 


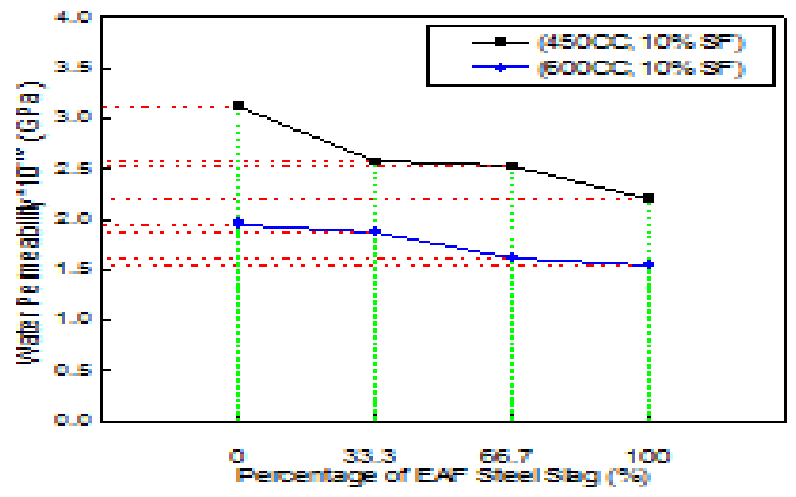

b) Mixes of $10 \% \mathrm{SF}$

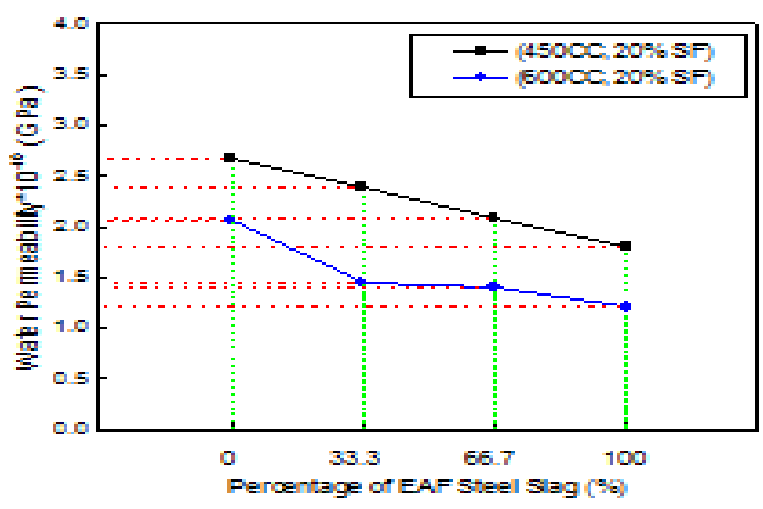

c) Mixes of $20 \% \mathrm{SF}$

Fig. 10. (a, b, c) Relationship between Permeability Coefficient and Percentage of Replacement of EAFSS Coarse Aggregate at 91 Days

\subsubsection{Effect of using of EAFSS fine aggregate with the EAFSS coarse aggregate}

Using of EAFSS fine aggregate produced porous or pervious concrete, see Figure (11). This means that, the using of EAFSS fine aggregate increased the voids ratio in the concrete mix and then caused a huge increase in the permeability coefficient the pressured water can easily penetrate the concrete samples.

It is well known that the major defect in the pervious concrete is the very low compressive strength of it. In the current research, despite the mixes of EAFSS fine aggregate which can be considered pervious concrete recorded lower compressive strength, mix M7.2 is still high strength concrete, see Table (12). 


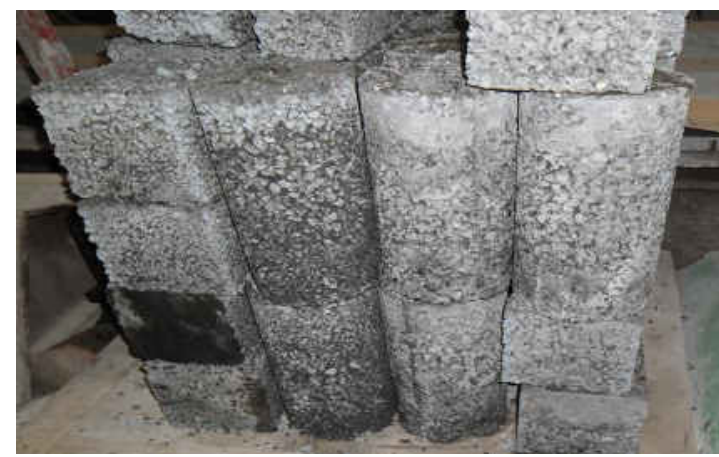

Fig. 11. The Appearance of Mixtures Prepared Using the EAFSS Fine and Coarse Aggregate

\section{Conclusions}

In this paper, properties of electric arc furnace steel slag were experimentally studied to be used as aggregate in normal, high, and ultra-high strength concrete. According to the results of the conducted experiments, the followings are drawn:

1- Recycling of electric arc furnace steel slag as aggregate in concrete proved to be an economical and environmentally friendly solution also this will encourage other investigations to find another filed of using the slag.

2- Due to appropriate physical and mechanical characteristics, it seems that utilization of electric arc furnace steel slag as aggregate in concrete has advantages compared to dolomite aggregate and it can make high and ultra-high strength concrete.

3- Results of the experiments which are carried out on hardened concrete, indicated that using of $66.67 \%$ as a replacement percentage of electric arc furnace steel slag to the natural coarse aggregate achieved the highest values of compressive strength, indirect tensile strength, flexural strength and modulus of elasticity in mixes with and without silica fume.

4- Replacement of EAFSS coarse aggregate by $66.67 \%$ at cement content $600 \mathrm{~kg} / \mathrm{m}^{3}$ produced ultra-high strength concrete. The compressive strength of mixes of $20 \%$ silica fume reached $125.7 \mathrm{MPa}$ after 91 days.

5- The enhancement in the compressive strength due to the increase in cement content achieved the highest value in mixes possessed replacement percentage of EAFSS coarse aggregate equals $66.67 \%$.

6- Using of EAFSS coarse aggregate enhanced the impermeability of the produced concrete. The reduction in the permeability coefficient reached about $50 \%$ of its original values in mixes of $0 \%$ silica fume.

7- Using of silica fume significantly improves the strength performance of the EAFSS concrete mixes.

8- Using of EAFSS as coarse and fine aggregate in concrete mixes increased the water permeability and produced porous or pervious concrete. Despite the mixes of coarse and fine EAFSS aggregates possessed large void ratio, high strength concrete still can be produced.

9- The high density of the produced concrete using EAFSS opens venue for several construction applications such as aggregates for road construction (e.g. surface layer, 
road base and sub base), breakwater blocks, foundations, shoring walls, a shield in nuclear plants, radiotherapy rooms and for transporting, and radiation insulators among others.

10- Effects of aggressive environments such as chlorides, sulfates, acids and high temperatures on the characteristics of the EAFSS concrete must be checked to demonstrate the advantages and disadvantages of this type of concrete.

\section{REFERENCES}

[1] Mohammed, K.J., F.O. Abbas, and M.O. Abbas. [2009] "Using of Steel Slag in Modification of Concrete Properties", Work. 13: p14.

[2] Qasrawi, H., F. Shalabi, and I. Asi. [2009] "Use of low $\mathrm{CaO}$ unprocessed steel slag in concrete as fine aggregate. Construction and Building Materials",. 23(2): p. 1118-1125.

[3] Patel, J.P. [2008] "Broader use of steel slag aggregates in concrete",Cleveland State University.

[4] Shekarchi M, A.R., Chini M, Ghods P, Hoseini M, Montazer S. [2003] "Study on electric arc furnace slag properties to be used as aggregates in concrete".

[5] Maslehuddin, M., et al.[2003] "Comparison of properties of steel slag and crushed limestone aggregate concretes", Construction and Building Materials. 17(2): p. 105112.

[6] Manso, J.M., et al .[2006] "Durability of concrete made with EAF slag as aggregate", Cement and Concrete Composites. 28(6): p. 528-534.

[7] Pellegrino, C. and V. Gaddo. [2009] "Mechanical and durability characteristics of concrete containing EAF slag as aggregate", Cement and Concrete Composites .(9) 31 : p. 663-671.

[8] Ramesh, S.T., et al.[2013] "Use of furnace slag and welding slag as replacement for sand in concrete", International Journal of Energy and Environmental Engineering. 4(1): p. 1-6.

[9] Chunlin, L., Z. Kunpeng, and C. Depeng, [2011]"Possibility of Concrete Prepared with Steel Slag as Fine and Coarse Aggregates", A Preliminary Study. Procedia Engineering. 24(0): p.412-416.

[10] Anastasiou, E., K. Georgiadis Filikas, and M. Stefanidou, [2014]"Utilization of fine recycled aggregates in concrete with fly ash and steel slag", Construction and Building Materials. 50(0): p. 154-161.

[11] Specification, E.S., "Cement-Physical and Mechanical Tests", ESS 2421/2005. Egyptian Standard Specification, "Aggregate for Concrete", ESS 1109/2002.

[12] "Egyptian Code of Practice for Design and Construction of Concrete Structures". ECCS (203-2007). 


\section{خواص للخرسانة عاليه المقاومه المحتوية علي ركام خبث الحديد المحلي}

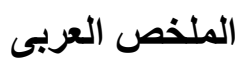

بدا الاهتمام بضروره الاستفاده من خبث الحديد المحلي نظر التفوق خو الصفه الفيه الفيزيائيه و الميكانيكيه مقارنه

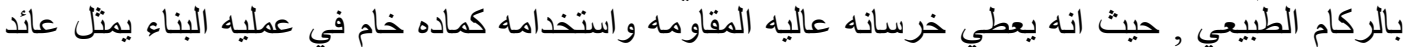

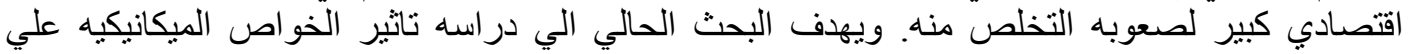

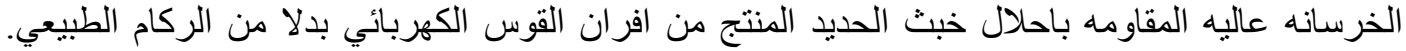

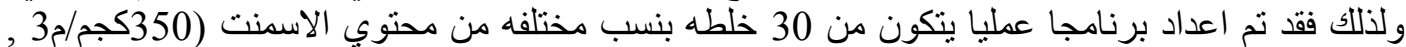
600450 كجم/23 , كجم/م3) مع اضافه السيليكا فيوم نسب ( المستخدم , وتم استبدال خبث الحديد بدلا من الركام الطبيعي الخشن بنسب (0) و

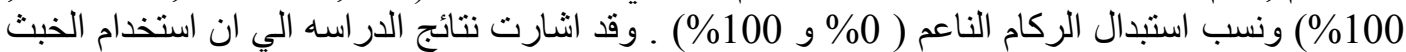

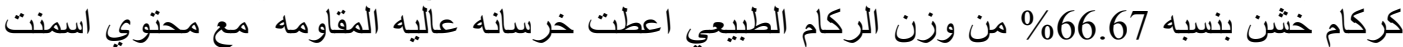

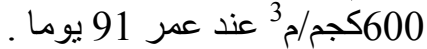

